\title{
Comparison of myofibrillar protein degradation, antioxidant profile, fatty acids, metmyoglobin reducing activity, physicochemical properties and sensory attributes of gluteus medius and infraspinatus muscles in goats
}

Kazeem D. Adeyemi ${ }^{1,5}$, Rafiat M. Shittu², Azad B. Sabow ${ }^{1,6}$, Ahmed A. Abubakar ${ }^{1}$, Roselina Karim², Saiful A. Karsani ${ }^{7}$ and Awis Q. Sazili ${ }^{1,3,4^{*}}$

\footnotetext{
Abstract

Background: The functionality of myofibrillar proteins is a major factor influencing the quality attributes of muscle foods. Nonetheless, the relationships between muscle type and oxidative changes in chevon during ageing are meagrely elucidated. Postmortem changes in antioxidant status and physicochemical properties of glycolytic gluteus medius (GM) and oxidative infraspinatus (IS) muscles in goats were compared.

Methods: Twenty Boer bucks (9-10 months old, body weight of $36.9 \pm 0.725 \mathrm{~kg}$ ) were slaughtered and the carcasses were subjected to chill storage $\left(4 \pm 0.5^{\circ} \mathrm{C}\right)$. Analyses were conducted on GM and IS muscles sampled on $0,1,4$ and 7 d postmortem.

\footnotetext{
*Correspondence: awis@upm.edu.my; awisqurni@gmail.com

${ }^{1}$ Department of Animal Science, Faculty of Agriculture, Universiti Putra Malaysia, 43400 UPM Serdang, Selangor, Malaysia

${ }^{3}$ Halal Products Research Institute, Universiti Putra Malaysia, 43400 UPM

Serdang, Selangor, Malaysia

Full list of author information is available at the end of the article
} 
(Continued from previous page)

Results: Chill storage did not affect the antioxidant enzyme activities in both muscles. The IS had greater $(P<0.05)$ superoxide dismutase and catalase activities than GM. Carotenoid and tocopherol contents did not differ between muscles but decreased $(P<0.05)$ over storage. The IS had higher $(P<0.05)$ glycogen and ultimate $\mathrm{pH}$ and lower $(P<0.05)$ shear force and cooking loss than GM. The carbonyl content, \% metmyoglobin, drip loss and TBARS increased $(P<0.05)$ while free thiol, metmyoglobin reducing activity (MRA), shear force and myoglobin decreased $(P<0.05)$ over storage. Muscle type had no effect $(P>0.05)$ on free thiol, MRA and TBARS. The GM had lower $(P<0.05)$ redness on $d 0$ and 1 than IS while the IS had greater carbonyl, \% metmyoglobin and drip loss than GM on $\mathrm{d}$ 7. The reflective density of slow myosin heavy chain $(\mathrm{MHC})$ was higher $(P<0.05)$ while the density of fast $\mathrm{MHC}$ and actin was lower $(P<0.05)$ in IS than GM. Regardless of muscle type, the density of MHC decreased $(P<0.05)$ while that of actin was stable over storage. Nonetheless, the degradation of fast and slow MHC was greater $(P<0.05)$ in IS than $\mathrm{GM}$. Muscle type had no effect $(P>0.05)$ on consumer preference for flavour, juiciness and overall acceptability. However, IS had higher $(P<0.05)$ tenderness score than GM on 11 and 4 postmortem. Intramuscular fat was higher $(P<0.05)$ in IS compared with GM. Fatty acid composition did not differ between the muscles. However, GM had lower $(P<0.05) n-6 / n-3$ ratio than IS. The n-3 and n-6 PUFA declined $(P<0.05)$ while the SFA increased $(P<0.05)$ over storage.

Conclusion: The changes in myofibrillar proteins and physicochemical properties of goat meat during postmortem chill storage are muscle-dependent.

Keywords: Actin, Antioxidants, Carbonyl, Myosin, Oxidation, Sensory

\section{Background}

Postmortem changes in muscle and its conversion to meat play an important role in meat quality [1]. Postmortem ageing is a common practice in the red meat industry. Ageing as used in this context, refers to the act of holding meat post-rigor at refrigeration temperatures for a given duration in order to improve meat quality traits, especially tenderness, and to supply chilled meat to distance markets [2]. Although the efficacy of postmortem ageing in achieving the aforementioned aims has been underscored $[1,2]$, postmortem ageing could have negative impact on the oxidative stability of lipids, myoglobin and myofibrillar proteins in meat [3-5]. Oxidative deterioration of lipids and proteins is the main cause of sensory, functional and nutritional quality deterioration in meat [3-6] and consumption of such products could have detrimental effect on human health [7].

The major factor controlling the oxidative stability of lipids and proteins is the antioxidant-pro-oxidant balance in the muscle [8-10]. Albeit endogenous antioxidant enzymes in muscle are functional in vivo, their ability to provide protection during postmortem may be short-lived $[4,10]$. The roles of postmortem ageing on lipid oxidation and physicochemical properties of beef [11, 12], mutton $[13,14]$ and goats $[9,15]$ have been documented. However, unlike beef [3-5] and mutton [14, 16], the impact of postmortem ageing on protein degradation and antioxidant enzyme activities are seldom explored in chevon.

Muscle type plays a vital role in ultimate meat quality $[1,17,18]$. Muscle fibre type is responsible for the variation in meat quality within and between muscles $[1,17$, 18]. The gluteus medius and infraspinatus are classified as fast glycolytic and slow oxidative muscle respectively [1, 17, 18]. Comparing the effect of postmortem ageing on these muscles could yield useful information as to the cuts of meat that could be best suited to chilled storage for long periods and most likely to have extended shelf-life. In addition, the biochemical and functional characteristics of each muscle type would likely cause different processing features, which would affect optimum utilization of muscle in value-added products [17, 18]. Despite the established differences between red and white muscles, their response to postmortem ageing and the relationships among antioxidant systems, oxidative deterioration and physicochemical properties of goat meat are unclear. Thus, the objective of this study was to compare the postmortem changes in antioxidant status, lipid oxidation, myofibrillar protein degradation, metmyoglobin reducing activity, fatty acid profile and physicochemical properties of gluteus medius and infraspinatus muscles in goats.

\section{Methods}

\section{Animals, slaughtering procedure and muscle sampling}

The study was conducted following the guidelines approved by the Universiti Putra Malaysia Institutional Animal Care and Use Committee. Qualified veterinarians who were members of the research team monitored the animals' health and welfare.

Twenty Boer crossbred bucks weighing $36.9 \pm 0.725 \mathrm{~kg}$ (mean \pm standard deviation), aged 9-10 months old and raised on $70 \%$ forage (oil palm frond) and $30 \%$ commercial concentrate were sourced from a local farm in Selangor, Malaysia. The goats were fasted overnight with ad libitum access to water and slaughtered according to 
the halal procedure [19] followed by evisceration and carcasses dressing. Each carcass was split along the vertebral column into left and right halves. All analyses were conducted on infraspinatus muscle (IS) and gluteus medius (GM) on the forelimb and hind limb respectively.

Muscle cuts were sampled from the right halve of each carcass on $0,1,4$ and $7 \mathrm{~d}$ postmortem. Twenty cuts from each of gluteus medius and infraspinatus muscle from twenty bucks were evaluated on each ageing period. On day $0,60 \mathrm{~g}$ of each muscle was dissected from the right half of each carcass, trimmed free of external fat and epimyseal connective tissue and divided into three parts. The first part $(15 \mathrm{~g})$ was snap frozen and pulverized in liquid nitrogen with porcelain mortar and pestle to produce a homogenous powder and assigned for the determination of glycogen, $\mathrm{pH}$, antioxidants, fatty acids, myoglobin, metmyoglobin, metmyoglobin reducing activity, lipid-protein oxidation, and SDS-PAGE at $\mathrm{d} 0$. The second part (15 g) was vacuum packaged and stored in a chiller at $4 \pm 1{ }^{\circ} \mathrm{C}$ for the determination of drip loss. The third part ( $30 \mathrm{~g}$ ) was assigned for the determination of colour, cooking loss and shear force on $\mathrm{d}$ 0. Muscle samples used for the sensory analysis were obtained from the left half of each carcass. The carcasses $(n=20)$ were hung in the chiller at $4 \pm 0.5{ }^{\circ} \mathrm{C}$ and subsequent sampling was carried out at 1,4 and $7 \mathrm{~d}$ postmortem. At the end of each ageing period, muscle cuts ( $45 \mathrm{~g}$ ) devoid of external fat and epimyseal connective tissue were dissected from the carcasses, and divided into two parts. The first part $(15 \mathrm{~g})$ was pulverized in liquid nitrogen and assigned as described earlier. The second part (30 g) was assigned for the determination of colour, cooking loss and shear force.

\section{Determination of muscle glycogen}

The glycogen content of pulverized muscles (GM, $n=20$; IS, $n=20$ for each ageing period) was determined using EnzyChrom $^{\text {TM }}$ Glycogen Assay kit (Cat\# E2GN-100, BioAssays, USA) following the procedure of the manufacturer. The assay was based on the hydrolysis of the glycogen content in each sample $(150 \mathrm{mg}$ ) to glucose by glucoamylase enzyme, oxidized to produce a product, which reacted with OxiRed probe. The colour generated from this reaction was measured at $570 \mathrm{~nm}$ using an auto microplate reader (infinite M200, Tecan, Austria). The colour intensity of the reaction product at $570 \mathrm{~nm}$ is directly proportional to the glycogen concentration in the sample.

\section{Determination of muscle $\mathrm{pH}$}

The $\mathrm{pH}$ of pulverized muscles (GM, $n=20$; IS, $n=20$ at each ageing period) was determined following the procedure of AMSA [20] using a pre calibrated portable $\mathrm{pH}$ meter (Mettler Toledo, AG 8603, Switzerland). The pH meter was calibrated with a $\mathrm{pH} 4.0$ buffer and then with a $\mathrm{pH} 7.0$ buffer prior to use. Each pulverized sample $(0.5 \mathrm{~g})$ was homogenized for $30 \mathrm{~s}$ with $10 \mathrm{~mL}$ of a $5 \mathrm{mM}$ sodium iodoacetate, $150 \mathrm{mM} \mathrm{KCl}$ solution [20]. The $\mathrm{pH}$ of the resultant homogenate was measured at $20 \pm 1{ }^{\circ} \mathrm{C}$ with the aid of the electrode attached to the $\mathrm{pH}$ meter.

\section{Determination of meat colour}

Meat colour coordinates were determined according to the method of AMSA [20] using a Colour Flex spectrophotometer (Hunter Lab, Reston, VA, USA) based on the International Commission on Illumination (CIE) Labvalues also known as lightness $\left(\mathrm{L}^{*}\right)$, redness $\left(\mathrm{a}^{*}\right)$ and yellowness $\left(\mathrm{b}^{*}\right)$ with $\mathrm{D}_{65}$ illuminant and $10^{\circ}$ standard observer, tristimulus values $(\mathrm{X}, \mathrm{Y}, \mathrm{Z})$ and reflectance at specific wavelength (400-700) $\mathrm{nm}$. The opening aperture size was $1.25 \mathrm{in}$. and the angle of geometry was $45^{\circ} / 0^{\circ}$. The device was calibrated against black and white reference tiles prior to use. The muscle samples (GM, $n=20$; IS, $n=20$ ) obtained on $0,1,4$ and $7 \mathrm{~d}$ were bloomed for $30 \mathrm{~min}$ at $27^{\circ} \mathrm{C}$ and the bloomed surface were placed facing the base of the colour flex cup and read. For each sample, triplicate readings for $\mathrm{L}^{*}, \mathrm{a}^{*}$ and $\mathrm{b}^{*}$ values were recorded and then averaged.

\section{Determination of myoglobin concentration}

The extraction and quantification of myoglobin followed the method of Warriss [21]. Three gram of pulverized muscle sample (GM, $n=20$; IS, $n=20$ at each ageing period) was homogenized with $15 \mathrm{~mL} 40 \mathrm{mM}$ potassium phosphate buffer ( $\mathrm{pH}$ 6.8). The homogenate was incubated on ice for $1 \mathrm{~h}$ and centrifuged (Avanti J-26XPI, BECKMAN COULTER ${ }^{\circ}$, USA) at 15, $000 \mathrm{~g}$ for $30 \mathrm{~min}$ at $4{ }^{\circ} \mathrm{C}$. The supernatant $(2 \mathrm{~mL})$ was filtered through Whatman No 1 filter paper and $1.25 \mathrm{~mL} 40 \mathrm{mM}$ phosphate buffer was added. The absorbance of the mixture was read at $540 \mathrm{~nm}$ using a spectrophotometer (Secomam, Domont, France). The concentration of the extracted pigment was estimated using absorbance value, dilution factor, molecular weight of myoglobin $(16,800)$, and a molar extinction coefficient of $114,000 \mathrm{M}^{-1} \mathrm{~cm}^{-1}$.

\section{Determination of metmyoglobin}

The percentage Metmyoglobin (\%MetMb) was determined as described by Krzywicki [22]. Three gram of pulverized muscle sample (GM, $n=20$; IS, $n=20$ at each ageing period) was homogenized with $15 \mathrm{~mL}$ ice cold $40 \mathrm{mM}$ phosphate buffer ( $\mathrm{pH}$ 6.8) for $15 \mathrm{~s}$. The homogenate was incubated on ice for $1 \mathrm{~h}$ and centrifuged (Avanti ${ }^{\circ}$ J-26XPI, BECKMAN COULTER', USA) at $6000 \mathrm{~g}$ for $20 \mathrm{~min}$ at $4{ }^{\circ} \mathrm{C}$. The supernatant was filtered through Whatman no 1 filter paper and the absorbance was read at 525, 545565 and 572 using a spectrophotometer 
(Secomam, Domont, France). The \% MetMb was estimated using the following formula:

$$
\begin{aligned}
\% \text { MetMb }=[ & -2.514(A 572 / A 525) \\
& +0.777(A 565 / A 525) \\
& +0.8(A 545 / A 525)+1.098] \times 100
\end{aligned}
$$

\section{Determination of metmyoglobin reducing activity}

Extraction of myoglobin reductase and determination of metmyoglobin reducing activity (MRA) in pulverized meat sample (GM, $n=20$; IS, $n=20$ at each ageing period) followed the procedure of Mikkelsen et al. [23].

\section{Determination of drip loss and cooking loss}

Drip and cooking losses were measured according to the method described by Sabow et al. [24] with slight modifications. For drip loss, fresh meat samples (GM, $n=20$, IS, $n=20)$ at $0 \mathrm{~d}$ were individually weighed and recorded as initial weight (W1). The weighed samples were placed into vacuum bags (2.5" x 10.0"; 3.0 mil transparent vacuum pouch with bottom tear notch), labelled, vacuum packaged (98\%) with a chamber Vacuum (CHTC-520LR) and stored at $4{ }^{\circ} \mathrm{C}$. After 1,4 and $7 \mathrm{~d}$ postmortem, the samples were removed from the bags, gently blotted dry, weighed and recorded as $W_{2}$. Drip loss was calculated and expressed as the percentage of difference between initial and final weight of sample after storage divide by initial weight of sample as shown in the equation below.

$$
\text { Driploss }(\%)=[(\mathrm{W} 1-\mathrm{W} 2) \div \mathrm{W} 1] \times 100
$$

For cooking loss, the meat samples (GM, $n=20$; IS, $n=$ 20 at each ageing period) used for colour measurements were individually weighed and recorded as initial weight (W1) and placed in vacuum bags (2.5" x 10.0"; $3.0 \mathrm{mil}$ transparent vacuum pouch with bottom tear notch), labelled, vacuum packaged (98\%) with a chamber Vacuum (CHTC-520LR). The samples were cooked in a pre-heated water bath set at $80{ }^{\circ} \mathrm{C}$. When the internal temperature of the samples reached $80{ }^{\circ} \mathrm{C}$ as monitored using a stabbing temperature probe (HI 145-00 thermometer, HANNA ${ }^{\circ}$ instruments, USA) inserted into the geometric centre of a representative sample, the cooked samples were removed from the water bath, equilibrated to room temperature and removed from the bags, blotted dry without squeezing, and reweighed (W2). The percentage cooking loss was calculated using the following equation:

$$
\text { Cooking loss }(\%)=[(\mathrm{W} 1-\mathrm{W} 2) \div \mathrm{W} 1] \times 100
$$

\section{Determination of shear force}

The samples obtained from the cooking loss analysis were used for the shear force analysis. Meat textural assessment was conducted using the TA.HD plus ${ }^{\bullet}$ texture analyzer (Stable Micro System, Surrey, UK) equipped with a Volodkevitch bite jaw. The equipment was calibrated at $5 \mathrm{~kg}$ for weight, $10 \mathrm{~mm}$ return distance for height and the blade speed was set at $10 \mathrm{~mm} / \mathrm{s}$. The sample preparation was conducted following the procedure of Sazili et al. [25]. From each sample, two replicate blocks $(2 \mathrm{~cm}$ length $x$ $1 \mathrm{~cm}$ width $\times 1 \mathrm{~cm}$ height) were cut parallel to the direction of the muscle fibres and each block was sheared in the centre perpendicular to the longitudinal direction of the fibres. Shear force was reported as the average peak positive force values for all blocks of individual sample.

\section{Sample preparation for sensory analysis}

The samples were trimmed free of external fat and epimyseal connective tissue. The meat samples ( $20 \mathrm{~g}$ each) were placed at the centre of a microwave oven (Elba $20 \mathrm{~L}$, EMO-A2072SV) and microwaved at $450 \mathrm{~W}$ for $5 \mathrm{~min}$ and the internal temperature was monitored with a stabbing temperature probe (HI 145-00 thermometer, HANNA ${ }^{\circ}$ instruments, USA). Preliminary investigation conducted to determine the length of cooking time required for the meat samples to reach internal temperature of $80{ }^{\circ} \mathrm{C}$ showed that the designated internal temperature could be reached within $5 \mathrm{~min}$ at $450 \mathrm{~W}$. No additive was added to the meat samples. Fifteen samples were microwaved at a time. Each sample was cut into a block $(2 \mathrm{~cm}$ length $\times$ $1 \mathrm{~cm}$ width $\times 1.27 \mathrm{~cm}$ height), wrapped in aluminium foil, coded with a three-digit random number and kept in the oven at $40{ }^{\circ} \mathrm{C}$ until analysis (the holding time was $1 \mathrm{~h}$ ). A total of 320 samples (GM, $n=40$; IS, $n=40$, at each ageing period) were subjected to sensory evaluation.

\section{Sensory assessors}

A consumer type sensory evaluation was conducted as described by Meilgaard et al. [26]. Forty assessors consisting of staff and students of Universiti Putra Malaysia participated in the sensory evaluation. The assessors were solicited via group emails and posters on faculty and departmental notice boards. Assessors were briefed on the sensory protocol and instructed on the parameters to judge $[26,27]$ using a 9-point hedonic scale. A value of nine indicated like extremely and one indicated dislike extremely. During the briefing section, definition and characteristics of each parameter (tenderness, juiciness, flavour, cooked colour and overall acceptability) and other sensory protocols were explained to the assessors before they entered the booth area. Evaluation was performed in individual booths (temperature, $23{ }^{\circ} \mathrm{C}$; relative humidity, $50 \%$ ) under a white fluorescent lighting. Evaluation was conducted for $1 \mathrm{~d}$ and two evaluation sessions were held with a 15 min break between sessions. In each session, four different samples (two different muscles at two different periods) were served and sample presentation was 
randomized. Deionized water was provided to rinse palate after tasting each sample.

\section{Determination of tocopherol and total carotenoids}

Extraction of tocopherol from pulverized muscles (GM, $n=20$; IS, $n=20$ at each ageing period) followed the method of Kamal-eldin et al. [28]. Quantification of tocopherol contents was done with Agilent 1200 series HPLC as described by Adeyemi et al. [29]. The carotenoid contents in pulverized meat samples were extracted and quantified as described by Adeyemi et al. [29].

\section{Antioxidant enzyme activity}

The Glutathione peroxidase (GPX) activity in pulverized samples (GM, $n=20$; IS, $n=20$ at each ageing period) was measured with the aid of EnzyChrom ${ }^{\text {ma }}$ Glutathione Peroxidase Assay Kit EGPX-100, (BioAssay Systems, USA). Superoxide Dismutase (SOD) activity was measured with the aid of Cayman SOD Assay kit (706002, Cayman chemical) while the catalase activity was measured using Cayman Catalase Assay Kit (707002, Cayman chemical) following the manufacturer's procedure. The amount of sample used for each of SOD, CAT and GPX analysis was $0.5 \mathrm{~g}$.

\section{Determination of lipid oxidation}

Lipid oxidation in pulverized muscle samples $(200 \mathrm{mg}$; GM, $n=20$; IS, $n=20$ at each ageing period) was measured as 2-thiobarbituric acid reactive substances (TBARS) using QuantiChrom ${ }^{\text {Tw }}$ TBARS Assay Kit (DTBA100, BioAssay Systems, USA) following the manufacturer's description. The assay was based on the reaction of thiobarbituric acid reactive substance (TBARS) with thiobarbituric acid (TBA) to form a pink coloured product. The colour intensity at $535 \mathrm{~nm}$ is directly proportional to TBARS ( $\mu \mathrm{M}$ malondialdehyde (MDA) equivalent) concentration in the sample.

\section{Determination of free thiol content}

Protein thiol in pulverized muscles (GM, $n=20$; IS, $n=20$ at each ageing period) was quantified according to Elman's method using 2,2-dithiobis (5-nitropyridine) DTNP [30] with slight modification as described by Morzel et al. [31]. Stock solution containing $4 \mathrm{mg}$ of myofibrillar proteins was dissolved in $3 \mathrm{~mL}$ of $100 \mathrm{mM}$ phosphate buffer at $\mathrm{pH} 8$ containing $8 \mathrm{M}$ urea. About $30 \mu \mathrm{l}$ of $10 \mathrm{mM}$ DTNP (stock solution in ethanol) was added, followed by incubation for $1 \mathrm{~h}$ at room temperature. The absorbance at $386 \mathrm{~nm}$ was measured using a spectronic ${ }^{\circ} 20$ GENESYS $^{\mathrm{ma}}$ spectrophotometer (Spectronic instruments, USA) against a blank of buffer without protein. The absorbance of the blank was subtracted, and thiol concentration was calculated using an absorption coefficient of $14 \mathrm{mM}^{-1} \mathrm{~cm}^{-1}$.

\section{Determination of carbonyl content}

The carbonyl content in pulverized muscles (200 mg; GM, $n=20$; IS, $n=20$ at each ageing period) was determined using Protein carbonyl colorimetric assay kit (10005020, Cayman Chemical) which utilized 2, 4 dinitrophenylhydrazine (DNPH) reactions to measure carbonyl content in tissues. The amount of protein-hydrozone produced was quantified by a spectrophotometer (infinite M200, Tecan, Austria) at $370 \mathrm{~nm}$ and the carbonyl content was standardized to protein concentration.

\section{Extraction of myofibrillar proteins and determination of protein concentration}

Myofibrillar proteins were isolated from pulverized muscles (GM, $n=20$; IS, $n=20$ at each ageing period) as described by Morzel et al. [31]. Pulverized muscle (2.5 g) was homogenized for $30 \mathrm{~s}$ on ice with $25 \mathrm{~mL}$ extraction buffer $(25 \mathrm{mM} \mathrm{KCl}, 150 \mathrm{mM} \mathrm{NaCl}, 4 \mathrm{mM}$ EDTA, $3 \mathrm{mM}$ $\mathrm{MgCl}_{2}$, at $\mathrm{pH}$ 6.5) to which protease inhibitor (CALBIO$\mathrm{CHEM}^{\circ}$, Cat \# 55140, EMD Bioscience, Inc. Germany) was added. The homogenate was filtered through $1.0 \mathrm{~mm}$ polyethylene strainer to eliminate any remaining collagen. After filtration, the homogenate was incubated at $4{ }^{\circ} \mathrm{C}$ with continuous shaking. This was followed by centrifugation at $2000 \mathrm{~g}$ for $15 \mathrm{~min}$ at $4{ }^{\circ} \mathrm{C}$. The pellet was washed twice with $25 \mathrm{~mL}$ of a $50 \mathrm{mM} \mathrm{KCl}$ solution at $\mathrm{pH} 6.4$ and once with $25 \mathrm{~mL}$ of $20 \mathrm{mM}$ phosphate buffer at pH 6 . The pellet was homogenized (T18 digital ULTRA-TURRAX ${ }^{\circ}$ IKA, Germany) in $5 \mathrm{~mL}$ of $20 \mathrm{mM}$ phosphate buffer for $1 \mathrm{~min}$ on ice. The homogenate was centrifuged (Avanti $\mathrm{J}^{\circ}$ 26XPI, BECKMAN COULTER ${ }^{\circ}$, USA) at $15,000 \mathrm{~g}$ for $20 \mathrm{~min}$ at $4{ }^{\circ} \mathrm{C}$. The total protein concentration of an aliquot of the clear supernatant was determined by the method of Bradford [32] using Protein Assay Kit II 5000002 (Bio-Rad, USA). The protein standards were prepared with Bovine serum albumen [33].

\section{Sodium dodecyl sulphate polyacrylamide gel electrophoresis (SDS-PAGE)}

The extracted myofibrillar proteins were incubated for $10 \mathrm{~min}$ at $90{ }^{\circ} \mathrm{C}$ in a sample buffer containing $2.3 \%(\mathrm{w} / \mathrm{v})$ SDS, $62.5 \mathrm{mM}$ Tris- $\mathrm{HCl}(\mathrm{pH}$ 6.8), $5 \%$ (v/v) mercaptoethanol, $0.05 \%(\mathrm{w} / \mathrm{v})$ bromophenol blue and $30 \%$ (v:v) glycerol. One dimensional SDS-PAGE was performed according to the method of Laemmli [34] using polyacrylamide gels of $8 \mathrm{~cm} \times 5.5 \mathrm{~cm}$ (length $\times$ width) and $0.8 \mathrm{~mm}$ thickness. The resolving gels were over-layered with $4 \%$ stacking gel solution. Samples (30 $\mu \mathrm{g}$ protein) were separated in running buffer $(0.025 \mathrm{~mol} / \mathrm{L}$ Tris base, $0.192 \mathrm{~mol} /$ L glycine, 0.1 SDS, pH 8.3) using a mini PROTEAN ${ }^{\circ}$ Tetra system (Bio-Rad) set at a constant voltage of $120 \mathrm{~V}$ and 0.4 A for $90 \mathrm{~min}$. Coomassie blue stain was used to stain the gels. The bands of actin and myosin heavy chain were 
visualized using GS-800 Calibrated Imaging Densitometer (Bio-Rad, USA).

\section{Western blotting}

The fractionated proteins that were initially separated from the samples based on their molecular weight through gel electrophoresis were transferred from the gel onto polyvinylidene difluoride (PVDF) membranes using Trans-Blot ${ }^{\circ}$ SD semi-dry transfer system cell (Bio-Rad, USA). Myosin heavy chain was transferred at constant amperage of $250 \mathrm{~mA}$ per gel, voltage limit of $25 \mathrm{~V}$ for $135 \mathrm{~min}$ whereas actin was transferred at the same amperage and voltage for $45 \mathrm{~min}$. After transfer, membranes were blocked for $3 \mathrm{~h}$ at room temperature in blocking solution [ $5 \%$ bovine serum albumin (BSA) in TBS-T buffer $(100 \mathrm{mM}$ Tris-HCl; $150 \mathrm{mM} \mathrm{NaCl} ; 0.05 \%$ Tween 20)]. Blots were washed thrice (10 min per wash) in PBS$\mathrm{T}$ and incubated overnight at room temperature with the primary antibody which was diluted 1: 500 in TBST containing 3 \% BSA. Monoclonal Anti-Myosin (Skeletal, Fast, produced in mouse; Cat \# M4276), Monoclonal Anti-Myosin (Skeletal, Slow, produced in mouse; Cat \# M842) and monoclonal Anti actin (produced in rabbit; Cat \# A2066 227) from Sigma- Aldrich, USA were the primary antibodies used for myosin heavy chain fast, myosin heavy chain slow and actin respectively. Subsequently, the membranes were incubated with secondary antibody [anti- mouse IgG (whole molecule) - peroxidase, antibody developed in rabbit; (Cat \# A9044) from Sigma- Aldrich, USA] diluted 1:10000 in $3 \%$ BSA in TBS-T buffer for $90 \mathrm{~min}$ at room temperature. This was followed by washing with TBS-T buffer thrice. The blocked membranes were detected using a DAB substrate kit Code: E885 (DAB SUBSTRATE SYSTEM (aMReSCO ${ }^{\circ}$, Solon, DH, USA). Myosin heavy chain and actin band intensities were measured using GS-800 Calibrated Imaging Densitometer (Bio-Rad, USA) using Quantify One ${ }^{\circ}$ software.

\section{Fatty acid analysis}

The total lipids in pulverized muscle samples (GM, $n=$ 20; IS, $n=20$, at each postmortem period) was extracted in chloroform: methanol $(2: 1, \mathrm{v} / \mathrm{v})$ mixture following the method of Folch et al. [35] modified by Rajion et al. [36]. The extracted fat was transmethylated to fatty acid methyl esters (FAME) using $2 \mathrm{~mL} 14 \% \mathrm{BF}_{3}$ and $2 \mathrm{~mL}$ $0.66 \mathrm{~N} \mathrm{KOH}$ in methanol (Sigma Chemical Co., St. Louis, MO, USA) according to the AOAC [37] method. The standard, column and the gas chromatography settings were described by Adeyemi et al. [38].

\section{Statistical analysis}

The sensory scores were checked for normality using the PROC UNIVARIATE procedure of SAS [39] and were found to be normally distributed. Data obtained from all parameters were analysed using the PROC MIXED procedure of SAS [39] in which muscle, postmortem chill storage and interaction between muscle and postmortem chill storage were fitted as fixed effects in a repeated measure analysis of variance. Before that, compound symmetry covariance structure, linear and quadratic contrasts were tested in regression analysis and found to have insignificant effects. Means were separated by Tukey HSD test at a significance level of $P<0.05$. Results were presented as mean \pm Standard error.

\section{Results and discussion}

\section{Muscle $\mathrm{pH}$ and glycogen}

The physicochemical properties of GM and IS muscles subjected to a $7 \mathrm{~d}$ postmortem chill storage are shown in Table 1. Regardless of the muscle, the $\mathrm{pH}$ and muscle glycogen observed on d 0 were higher $(P<0.05)$ compared with those observed on other storage days. This observation could be due to postmortem glycolysis. The cessation of blood circulation at death shifts muscle metabolism from aerobic to anaerobic, which necessitates the conversion of glycogen to lactic acid responsible for the decrease in muscle $\mathrm{pH}[1,40]$. The $\mathrm{pH}$ and glycogen content observed on d 1, 4 and 7 were not significantly different $(P>0.05)$. This indicates that postmortem glycolysis was completed during the first $24 \mathrm{~h}$ postmortem. The current finding is akin to that of Kadim et al. [41] who reported that the $\mathrm{pH}$ of longissimus dorsi, biceps femoris, semitendinosus, and semimembranosus muscles from different Omani breeds of goats observed on d 1 was similar to those observed on d 6 postmortem.

The IS muscle had greater $(P<0.05)$ glycogen content than GM on $d 1,4$ and 7. In addition, the IS had higher $(P<0.05) \mathrm{pH}$ than GM throughout storage. This finding could be attributed to the inherent differences in fibre types and postmortem energy metabolism between the muscles $[17,18]$. Glycolytic muscles are more responsive to postmortem glycolysis because they have higher concentration of inorganic phosphate, which stimulates the conversion of glycogen to lactic acid [1, 17]. The current observations are in tandem with those of Sitthigripong et al. [42] who observed a higher $\mathrm{pH}$ in supraspinatus, infraspinatus and psoas major compared with longissimus dorsi from Boer crossbred goats. There was no significant interaction between muscle type and postmortem chill storage for the $\mathrm{pH}$ and glycogen content in goat meat.

\section{Drip and cooking losses}

The drip and cooking losses of IS and GM muscles during postmortem refrigerated storage are shown in Table 1 . Regardless of muscle, drip loss increased $(P<0.05)$ over storage. This observation could be due to the reduction in the available space (steric effects) for water to reside in the muscle due to the formation of cross-bridges between the 
Table 1 Physicochemical properties of infraspinatus (IS) and gluteus medius (GM) muscles in goats during postmortem chill storage

\begin{tabular}{|c|c|c|c|c|c|c|c|}
\hline \multirow[b]{2}{*}{ Parameter } & \multirow[b]{2}{*}{ Muscle } & \multicolumn{4}{|c|}{ Storage time (days) } & \multicolumn{2}{|c|}{$P$ value } \\
\hline & & 0 & 1 & 4 & 7 & Storage & Muscle $\times$ storage \\
\hline \multirow[t]{3}{*}{$\mathrm{pH}$} & IS & $6.61 \pm 0.110^{a y}$ & $5.87 \pm 0.111^{\text {by }}$ & $5.89 \pm 0.140^{\text {by }}$ & $5.88 \pm 0.102^{\text {by }}$ & $<.0001$ & \\
\hline & GM & $6.34 \pm 0.031^{\mathrm{ax}}$ & $5.60 \pm 0.101^{b x}$ & $5.60 \pm 0.310^{b x}$ & $5.59 \pm 0.221^{b x}$ & 0.001 & 0.091 \\
\hline & $P$ value & 0.012 & 0.001 & 0.012 & 0.021 & & \\
\hline \multirow[t]{3}{*}{ Glycogen (mg/g) } & IS & $1.35 \pm 0.010^{\mathrm{a}}$ & $0.68 \pm 0.023^{\text {by }}$ & $0.64 \pm 0.011^{\text {by }}$ & $0.65 \pm 0.010$ by & $<.0001$ & \\
\hline & GM & $1.30 \pm 0.030^{\mathrm{a}}$ & $0.58 \pm 0.012^{b x}$ & $0.56 \pm 0.011$ bx & $0.57 \pm 0.012^{b x}$ & $<.0001$ & 0.100 \\
\hline & $P$ value & 0.213 & 0.021 & 0.011 & 0.019 & & \\
\hline \multirow[t]{3}{*}{ Drip loss (\%) } & IS & - & $3.55 \pm 0.342^{c}$ & $4.67 \pm 0.481^{b}$ & $6.05 \pm 0.731^{\text {ay }}$ & $<.0001$ & \\
\hline & GM & - & $2.80 \pm 0.110^{c}$ & $3.98 \pm 0.210^{b}$ & $4.72 \pm 0.140^{\mathrm{ax}}$ & $<.0001$ & 0.104 \\
\hline & $P$ value & & 0.090 & 0.080 & 0.023 & & \\
\hline \multirow[t]{3}{*}{ Cooking loss (\%) } & IS & $38.22 \pm 0.532^{\mathrm{ax}}$ & $33.27 \pm 0.230^{b x}$ & $34.54 \pm 0.682^{b}$ & $34.48 \pm 0.920^{b}$ & $<.0001$ & \\
\hline & GM & $42.12 \pm 0.651^{\text {ay }}$ & $37.87 \pm 0.471^{\text {by }}$ & $36.67 \pm 0.701^{b}$ & $36.79 \pm 0.991^{b}$ & 0.0431 & 0.120 \\
\hline & $P$ value & 0.029 & 0.014 & 0.072 & 0.064 & & \\
\hline \multirow[t]{3}{*}{ Shear force (kg) } & IS & $1.21 \pm 0.011^{\mathrm{ax}}$ & $0.89 \pm 0.042^{\mathrm{bx}}$ & $0.83 \pm 0.011^{b c x}$ & $0.77 \pm 0.020^{c}$ & 0.0275 & 0.224 \\
\hline & GM & $1.32 \pm 0.041^{\text {ay }}$ & $0.94 \pm 0.021^{\text {by }}$ & $0.88 \pm 0.012^{\text {bcy }}$ & $0.80 \pm 0.042^{c}$ & $<.0001$ & \\
\hline & $P$ value & 0.023 & 0.015 & 0.016 & 0.201 & & \\
\hline \multirow[t]{3}{*}{ Lightness ( $\left(L^{*}\right)$} & IS & $32.64 \pm 0.470^{b}$ & $33.26 \pm 0.850^{b}$ & $37.77 \pm 1.152^{\mathrm{a}}$ & $37.52 \pm 0.464^{a}$ & 0.004 & 0.126 \\
\hline & GM & $34.04 \pm 0.220^{b}$ & $34.98 \pm 0.111^{b}$ & $37.22 \pm 1.201^{\mathrm{a}}$ & $38.02 \pm 1.013^{\mathrm{a}}$ & 0.002 & \\
\hline & $P$ value & 0.061 & 0.258 & 0.078 & 0.069 & & \\
\hline \multirow[t]{3}{*}{ Redness $\left(a^{*}\right)$} & IS & $13.24 \pm 0.221^{\text {ay }}$ & $14.12 \pm 0.261^{\text {ay }}$ & $10.70 \pm 0.690^{b}$ & $8.83 \pm 0.180^{c x}$ & $<.0001$ & 0.113 \\
\hline & GM & $11.20 \pm 0.142^{\mathrm{ax}}$ & $12.02 \pm 0.111^{\mathrm{ax}}$ & $10.23 \pm 0.160^{b}$ & $9.45 \pm 0.171^{c y}$ & 0.002 & \\
\hline & $P$ value & 0.012 & 0.038 & 0.500 & 0.019 & & \\
\hline \multirow[t]{3}{*}{ Yellowness (b*) } & IS & $13.38 \pm 0.470$ & $13.76 \pm 0.150$ & $11.64 \pm 1.442$ & $13.92 \pm 0.882$ & 0.288 & 0.183 \\
\hline & GM & $13.14 \pm 0.231$ & $12.98 \pm 0.712$ & $12.47 \pm 0.221$ & $12.33 \pm 0.332$ & 0.543 & \\
\hline & $P$ value & 0.231 & 0.106 & 0.114 & 0.321 & & \\
\hline \multirow[t]{3}{*}{ Myoglobin (mg/g) } & IS & $3.21 \pm 0.143^{\text {ay }}$ & $2.94 \pm 0.072^{\mathrm{ay}}$ & $2.74 \pm 0.083^{b}$ & $2.68 \pm 0.111^{b}$ & 0.020 & 0.156 \\
\hline & GM & $2.89 \pm 0.110^{\mathrm{ax}}$ & $2.80 \pm 0.122^{\mathrm{ax}}$ & $2.71 \pm 0.041^{b}$ & $2.60 \pm 0.122^{b}$ & 0.013 & \\
\hline & $P$ value & 0.032 & 0.022 & 0.091 & 0.213 & & \\
\hline \multirow[t]{3}{*}{ Metmyoglobin (\%) } & IS & $2.83 \pm 0.252^{d}$ & $7.19 \pm 0.391^{c}$ & $12.77 \pm 0.480^{b}$ & $20.47 \pm 0.571^{\text {ay }}$ & $<.0001$ & 0.120 \\
\hline & GM & $2.91 \pm 0.433^{d}$ & $7.39 \pm 0.222^{c}$ & $12.35 \pm 0.232^{b}$ & $18.99 \pm 0.110^{\mathrm{ax}}$ & 0.002 & \\
\hline & $P$ value & 0.156 & 0.412 & 0.210 & 0.046 & & \\
\hline \multirow[t]{3}{*}{$\operatorname{MRA}^{1}(\mathrm{nmol} / \mathrm{min} / \mathrm{g})$} & is & $200.06 \pm 2.081^{a}$ & $189.50 \pm 5.001^{\mathrm{ab}}$ & $180.44 \pm 6.562^{b}$ & $169.08 \pm 4.920^{c}$ & 0.043 & 0.189 \\
\hline & GM & $212.77 \pm 3.112^{\mathrm{a}}$ & $200.45 \pm 3.232^{b}$ & $190.22 \pm 4.113^{c}$ & $151.90 \pm 3.120^{d}$ & 0.004 & \\
\hline & $P$ value & 0.216 & 0.120 & 0.147 & 0.548 & & \\
\hline
\end{tabular}

$\mathrm{a}, \mathrm{b} c$ means having different superscripts along the same row are significantly different $(P<0.05){ }^{x, y}$ means having different superscripts along the same column are significantly different $(P<0.05) .{ }^{1}$ metmyoglobin reducing activity

thick and thin myofibrillar filaments during rigor development $[43,44]$. In addition, as the muscle reaches rigor, the $\mathrm{pH}$ of the tissue nears the isoelectric point of many of the major proteins (particularly myosin), thereby reducing the amount of water that is attracted to protein structures in the myofibril [45]. Similar increase in drip loss was observed during postmortem ageing of chevon $[9,46]$.

The IS muscle had higher $(P<0.05)$ drip loss than GM on $\mathrm{d} 7$ postmortem. This observation was contrary to our expectation given the higher $\mathrm{pH}$ in IS compared with GM. A high ultimate $\mathrm{pH}$, above the isoelectric point of myofibrillar proteins enhances the water holding capacity of meat $[43,45]$. Thus, the higher drip loss in IS could be due to its greater $(P<0.05)$ degradation of myofibrillar proteins (Table 4) and greater carbonyl content on $\mathrm{d} 7$ (Table 3). There was a positive correlation between drip loss and degradation of myofibrillar proteins during ageing of meat $[45,47]$. 
Irrespective of muscle, the cooking loss observed on $\mathrm{d} 0$ was greater $(P<0.05)$ than that observed on other storage days. This observation could be due to the degradation of cytoskeletal proteins, which reduces rigor-induced lateral shrinkage of myofibrils thereby reducing the amount of water expelled [48]. This observation corroborates the findings of Sabow et al. [24] who observed that d 0 cooking loss in longissimus lumborum muscle in goats was greater than those observed on other storage days.

Cooking loss was stable from 1 to $7 \mathrm{~d}$ postmortem in both muscles. This observation could be due to the stability of $\mathrm{pH}$. The GM had higher $(P<0.05)$ cooking loss than IS on $\mathrm{d} 0$ and 1 postmortem. This could be attributed to the higher $(P<0.05) \mathrm{pH}$ of IS compared with GM. The induction of a high ultimate $\mathrm{pH}$ in muscle will diminish that particular portion of the cooking loss, which is due to the exudation of moisture $[1,49]$. In addition, the higher cooking loss in GM could be due to its lower intramuscular fat than IS (Table 5). Intramuscular fat possibly loosen up the microstructure, thus allowing more water to be entrained [1, 45]. Similarly, glycolytic semitendinosus muscle had higher cooking loss than oxidative supraspinatus muscle in goats [50]. There was no significant interaction between muscle type and chill storage for drip and cooking losses in goat meat.

\section{Shear force values}

Postmortem chill storage was a significant $(P<0.05)$ source of variation affecting shear force in goat meat (Table 1). Regardless of the muscle, there was a reduction $(P<0.05)$ in shear force from d 0 to 7 postmortem. Postmortem improvement in meat tenderness could be due to the weakening of myofibrillar structure by endogenous muscle proteinases $[1,40]$. Similarly, a decrease in shear force was observed during postmortem ageing of chevon $[9,24]$. The IS had lower $(P<0.05)$ shear force than GM on $\mathrm{d} 0,1$ and 4 postmortem. This observation could be due to the higher $(P<0.05)$ intramuscular fat (Table 5$)$ and lower cooking loss (Table 1) in IS compared with GM. Intramuscular fat increases expansion of fat cell in the perimysial connective tissue, which forces muscle bundles apart, thus opening up the muscle structure [1]. This finding could also be due to the high ultimate $\mathrm{pH}$ in IS which favours calpain activities thereby improving meat tenderness [51]. The relative proportions of connective tissue vary between muscles and, in part, account for the relative toughness of meat [1]. White muscles have a higher connective tissue than red muscles [1]. Terrescano et al. [52] observed that oxidative psoas major and diaphragma had lower shear force, total collagen and insoluble collagen compared with glycolytic gluteus medius and semimembranosus in beef. In addition, Aghwan [50] observed a lower shear force in oxidative supraspinatus muscle than glycolytic semitendinosus muscles in goats.

\section{Meat colour}

Postmortem chill storage influenced $(P<0.05)$ the redness $\left(\mathrm{a}^{*}\right)$ and lightness $\left(\mathrm{L}^{*}\right)$ of GM and IS muscles in goats (Table 1). Neither muscle nor chill storage influenced yellowness $\left(b^{*}\right)$ of goat meat. The $L^{*}$ and $a^{*}$ values increased and decreased $(P<0.05)$ respectively from $\mathrm{d} 1$ to 7 postmortem. This observation could be due to the decrease $(P<0.05)$ in myoglobin concentration and metmyoglobin reducing activity (MRA) and the increase $(P<$ $0.05)$ in \% metmyoglobin as storage progressed. The improvement in $\mathrm{L}^{*}$ and the decrease in $\mathrm{a}^{*}$ over storage concur with previous findings in chevon [9], beef [12] and mutton [13]. The IS had higher redness compared with GM on day 0 and 1 postmortem. This could be due to the higher concentration of oxygenated myoglobin in IS compared with GM [1, 17, 18]. Similarly, Mercier et al. [53] reported a higher $\mathrm{a}^{*}$ in oxidative sartorius than glycolytic pectoralis major in turkey.

\section{Myoglobin (Mb), \% metmyoglobin (MetMb) and metmyoglobin reducing activity (MRA)}

Postmortem chill storage had significant $(P<0.05)$ effect on $\mathrm{Mb}$, and \% MetMb in IS and GM muscles in goats (Table 1). Irrespective of muscle, the concentration of Mb observed on d 0 and 1 did not differ $(P>0.05)$ but was greater $(P<0.05)$ than those observed on $\mathrm{d} 4$ and 7 . The \% MetMb increased $(P<0.05)$ over storage in both muscles. These observations could be due to the oxidation of $\mathrm{Mb}$ or oxymyoglobin to form MetMb $[12,13]$. Similarly, the \% MetMb of beef patties subjected to an 8 $\mathrm{d}$ [12] and a $10 \mathrm{~d}$ [11] chill storage increased as storage continued.

The IS had higher $\mathrm{Mb}$ than GM on $\mathrm{d} 0$ and 1 . In addition, the \% MetMb was higher in IS compared with GM on $\mathrm{d} 4$ and 7 postmortem. These observations lend credence to the higher $(P<0.05)$ redness on $\mathrm{d} 0$ and 1 and lower redness on $\mathrm{d} 7$ in IS compared with GM. These observations are consistent with those of Renerre et al. [4] who observed that oxidative diaphragma and psoas major had greater \% MetMb and lower colour stability than glycolytic longissimus lumborum and tensor fasciae latae during an $8 \mathrm{~d}$ postmortem storage of beef.

The MRA decreased $(P<0.05)$ as postmortem conditioning progressed (Table 1). On $\mathrm{d} 7$, there was a $15 \%$ and $23 \%$ reduction in the original MRA in the GM and IS respectively. This finding is in tandem with that of Madhavi and Carpenter [54] who observed a $20 \%$ reduction in MRA of beef from d 2 to 21 postmortem. In contrast, there was a significant increase in the MRA of beef patties over an $8 \mathrm{~d}$ [12] and a $10 \mathrm{~d}$ [11] refrigerated storage. Bekhit et al. [13] observed that the MRA in ovine longissimus muscle was stable throughout a $10 \mathrm{~d}$ chill storage. The discrepancies among studies with respect to the effect of postmortem storage on MRA of meat could be due to 
the differences in methodology employed, the rate of myoglobin oxidation and efficacy of one or more enzymes required for reducing the formed metmyoglobin [55]. The MRA was not significantly different $(P>0.05)$ between GM and IS throughout storage. Interaction between muscle type and chill storage was not significant $(P>0.05)$ for myoglobin, \% metmyoglobin and MRA in goat meat.

\section{Sensory attributes}

The effects of muscle type and postmortem chill storage on meat sensory scores are presented in Table 2. In both muscles, assessors ranked meat samples tasted on $\mathrm{d} 1,4$ and 7 as more tender $(P<0.05)$ and having greater overall acceptance $(P<0.05)$ than $\mathrm{d} 0$ samples. This could be due to the postmortem weakening of myofibrillar proteins in the course of ageing [1, 51]. This coincides with the decrease $(P<0.05)$ in the instrumental shear force as storage progressed (Table 1). Consumers ranked d 0 meat samples as juicer $(P<0.05)$ compared with those tasted on other storage days. Chill storage had no effect $(P>0.05)$ on the liking of flavour and cooked colour of goat meat. Muscle type had no effect $(P>0.05)$ on the consumer preference for cooked colour, flavour, juiciness and overall acceptability of goat meat throughout storage. However, consumers ranked IS as tenderer $(P<0.05)$ than GM on $\mathrm{d}$ 1,4 and 7 postmortem. This could be attributed to the lower $(P<0.05)$ cooking loss and instrumental shear force in IS compared with GM (Table 1). A lower cooking loss is likely to improve tenderness because a given crosssectional area of meat sample will contain more water and less structural components [49]. There was no significant interaction $(P>0.05)$ between muscle type and chill storage for the sensory scores of goat meat.

\section{Antioxidant enzyme activities, tocopherol and carotenoid} The antioxidant enzyme activities and concentration of carotenoid and tocopherol in GM and IS muscles during chill storage are shown in Table 3. Regardless of the muscle, the catalase (CAT), glutathione peroxidase (GPX) and superoxide dismutase (SOD) activities were unaffected $(P>$ $0.05)$ by chill storage. There was no significant correlation (data not shown) between antioxidant enzyme activities and indicators of quality deterioration in goat meat. The effects of chill storage on antioxidant enzyme activities in meat has yielded inconsistent results in the published literature. Renerre et al. [4] observed that the GPX and CAT activities in bovine muscles on $\mathrm{d} 1$ was similar to those observed on $\mathrm{d} 8$ postmortem. However, the authors observed that SOD activity declined over the $8 \mathrm{~d}$ storage. Renerre et al. [8] observed a non-significant reduction in SOD but a significant decrease in GPX in pectoralis major muscle of turkey over a $9 \mathrm{~d}$ chill storage.

The activities of SOD and CAT were greater $(P<0.05)$ in IS compared with GM throughout storage. However, GPX activity was not influenced by muscle type. These observations are consistent with those of Renerre et al. [4] who observed higher SOD and CAT activities in oxidative diaphragma compared with glycolytic longissimus lumborum during an $8 \mathrm{~d}$ postmortem storage of beef. In turkey, Renerre et al. [8] observed that oxidative sartorius had higher SOD and CAT than glycolytic pectoralis major during a $9 \mathrm{~d}$ postmortem ageing. Interaction between

Table 2 Sensory attributes of infraspinatus (IS) and gluteus medius (GM) muscles in goats during postmortem chill storage

\begin{tabular}{|c|c|c|c|c|c|c|c|}
\hline \multirow[b]{2}{*}{ Parameter } & \multirow[b]{2}{*}{ Muscle } & \multicolumn{4}{|c|}{ Storage time (days) } & \multicolumn{2}{|c|}{$P$ value } \\
\hline & & 0 & 1 & 4 & 7 & Storage & Muscle $\times$ storage \\
\hline \multirow[t]{3}{*}{ Juiciness } & IS & $7.81 \pm 0.200^{\mathrm{a}}$ & $6.84 \pm 0.161^{b}$ & $6.19 \pm 0.140^{b}$ & $6.98 \pm 0.101^{b}$ & 0.043 & \\
\hline & GM & $7.73 \pm 0.030^{\mathrm{a}}$ & $6.70 \pm 0.322^{b}$ & $6.10 \pm 0.210^{b}$ & $6.89 \pm 0.520^{b}$ & 0.023 & 0.091 \\
\hline & $P$ value & 0.101 & 0.201 & 0.463 & 0.110 & & \\
\hline \multirow[t]{3}{*}{ Tenderness } & IS & $6.35 \pm 0.010^{\mathrm{a}}$ & $8.38 \pm 0.021^{\mathrm{bx}}$ & $8.64 \pm 0.010^{b x}$ & $8.60^{\text {by }} \pm 0.012$ & 0.041 & \\
\hline & GM & $6.30 \pm 0.031^{a}$ & $7.78 \pm 0.010^{\text {by }}$ & $7.65 \pm 0.010^{\text {by }}$ & $7.99^{b x} \pm 0.011$ & 0.011 & 0.108 \\
\hline & $P$ value & 0.213 & 0.011 & 0.019 & 0.009 & & \\
\hline \multirow[t]{3}{*}{ Flavor } & IS & $7.70 \pm 0.441$ & $7.12 \pm 0.433$ & $7.43 \pm 0.842$ & $7.31 \pm 0.774$ & 0.876 & \\
\hline & GM & $7.65 \pm 0.532$ & $7.19 \pm 0.192$ & $7.19 \pm 0.141$ & $7.60 \pm 0.671$ & 0.231 & 0.428 \\
\hline & $P$ value & 0.890 & 0.090 & 0.080 & 0.083 & & \\
\hline \multirow[t]{3}{*}{ Cooked colour } & IS & $7.22 \pm 0.531$ & $7.27 \pm 0.231$ & $7.54 \pm 0.682$ & $7.80 \pm 0.922$ & 0.331 & \\
\hline & GM & $7.12 \pm 0.652$ & $7.87 \pm 0.472$ & $7.17 \pm 0.701$ & $7.79 \pm 0.991$ & 0.234 & 0.101 \\
\hline & $P$ value & 0.392 & 0.104 & 0.172 & 0.106 & & \\
\hline \multirow[t]{3}{*}{ Overall acceptability } & IS & $7.51 \pm 0.712^{\mathrm{a}}$ & $8.33 \pm 0.760^{b}$ & $8.03 \pm 0.820^{b}$ & $8.03 \pm 0.510^{b}$ & 0.025 & 0.224 \\
\hline & GM & $7.52 \pm 0.541^{\mathrm{a}}$ & $8.45 \pm 0.720^{b}$ & $8.05 \pm 0.811^{b}$ & $8.03 \pm 0.842^{b}$ & 0.043 & \\
\hline & $P$ value & 0.135 & 0.111 & 0.147 & 0.126 & & \\
\hline
\end{tabular}

a, b c means having different superscripts along the same row are significantly different $(P<0.05) .{ }^{x, y}$ means having different superscripts along the same column are significantly different $(P<0.05)$ 
Table 3 Antioxidant status, protein degradation and lipid oxidation in infraspinatus (IS) and gluteus medius (GM) muscles in goats during postmortem chill storage

\begin{tabular}{|c|c|c|c|c|c|c|c|}
\hline \multirow[b]{2}{*}{ Parameter } & \multirow[b]{2}{*}{ Muscle } & \multicolumn{4}{|c|}{ Storage time (days) } & \multicolumn{2}{|c|}{$P$ value } \\
\hline & & 0 & 1 & 4 & 7 & Storage & Storage $\times$ muscle \\
\hline \multirow[t]{3}{*}{ a-tocopherol (mg/kg) } & IS & $2.19 \pm 0.130^{a}$ & $2.01 \pm 0.100^{b}$ & $1.43 \pm 0.061^{c}$ & $1.16 \pm 0.020^{c}$ & $<.0001$ & 0.192 \\
\hline & GM & $2.14 \pm 0.111^{a}$ & $1.93 \pm 0.120^{b}$ & $1.40 \pm 0.032^{c}$ & $1.23 \pm 0.040^{c}$ & 0.0012 & \\
\hline & $P$ value & 0.217 & 0.140 & 0.223 & 0.123 & & \\
\hline \multirow[t]{3}{*}{ y-tocopherol (mg/kg) } & IS & $0.69 \pm 0.051^{a}$ & $0.65 \pm 0.052^{a}$ & $0.41 \pm 0.010^{b}$ & $0.23 \pm 0.020^{c}$ & $<.0001$ & 0.237 \\
\hline & GM & $0.70 \pm 0.022^{a}$ & $0.65 \pm 0.021^{a}$ & $0.44 \pm 0.040^{b}$ & $0.27 \pm 0.010^{c}$ & $<.0001$ & \\
\hline & $P$ value & 0.532 & 0.112 & 0.267 & 0.417 & & \\
\hline \multirow[t]{3}{*}{ S-tocopherol (mg/kg) } & IS & $0.08 \pm 0.011$ & $0.08 \pm 0.012$ & $0.07 \pm 0.011$ & $0.07 \pm 0.011$ & 0.109 & 0.280 \\
\hline & GM & $0.12 \pm 0.031$ & $0.10 \pm 0.011$ & $0.09 \pm 0.021$ & $0.09 \pm 0.031$ & 0.204 & \\
\hline & $P$ value & 0.211 & 0.234 & 0.091 & 0.094 & & \\
\hline \multirow[t]{3}{*}{ Total carotenoid (mg/kg) } & IS & $0.27 \pm 0.010^{a}$ & $0.23 \pm 0.011^{a}$ & $0.18 \pm 0.012^{b}$ & $0.11 \pm 0.010^{c}$ & $<.0001$ & 0.447 \\
\hline & GM & $0.25 \pm 0.030^{\mathrm{a}}$ & $0.22 \pm 0.012^{\mathrm{a}}$ & $0.15 \pm 0.041^{b}$ & $0.10 \pm 0.030^{c}$ & 0.004 & \\
\hline & $P$ value & 0.901 & 0.548 & 0.071 & 0.361 & & \\
\hline \multirow[t]{3}{*}{ Catalase $^{1}$} & IS & $1828.9 \pm 27.23^{y}$ & $1820.0 \pm 20.83^{y}$ & $1844.2 \pm 21.91^{y}$ & $1816.3 \pm 26.80^{y}$ & 0.190 & 0.135 \\
\hline & GM & $1666.2 \pm 11.80^{x}$ & $1767.0 \pm 10.20^{x}$ & $1515.2 \pm 12.11^{x}$ & $1700.2 \pm 17.10^{x}$ & 0.219 & \\
\hline & $P$ value & 0.012 & 0.009 & 0.034 & 0.022 & & \\
\hline \multirow[t]{3}{*}{$S O D^{2}$} & IS & $3.14 \pm 0.161^{y}$ & $3.07 \pm 0.121^{y}$ & $3.31 \pm 0.212^{y}$ & $3.17 \pm 0.05^{y}$ & 0.742 & 0.221 \\
\hline & GM & $2.70 \pm 0.132^{x}$ & $2.45 \pm 0.143^{x}$ & $2.87 \pm 0.111^{x}$ & $2.78 \pm 0.05^{\times}$ & 0.092 & \\
\hline & $P$ value & 0.030 & 0.002 & 0.043 & 0.012 & & \\
\hline \multirow[t]{3}{*}{$\mathrm{GPX}^{3}$} & IS & $66.75 \pm 2.621$ & $63.42 \pm 3.500$ & $65.03 \pm 2.772$ & $63.01 \pm 0.940$ & 0.806 & 0.156 \\
\hline & GM & $65.20 \pm 1.600$ & $59.89 \pm 1.250$ & $63.11 \pm 2.112$ & $62.22 \pm 1.332$ & 0.418 & \\
\hline & $P$ value & 0.190 & 0.090 & 0.301 & 0.128 & & \\
\hline \multirow[t]{3}{*}{ TBARS (mg MDA/kg) } & IS & $0.12 \pm 0.010^{c}$ & $0.15 \pm 0.011^{c}$ & $0.19 \pm 0.010^{b}$ & $0.28 \pm 0.010^{a}$ & $<.0001$ & 0.173 \\
\hline & GM & $0.11 \pm 0.010^{c}$ & $0.13 \pm 0.020^{c}$ & $0.18 \pm 0.030^{b}$ & $0.26 \pm 0.031^{a}$ & $<0.001$ & \\
\hline & $P$ value & 0.130 & 0.273 & 0.112 & 0.367 & & \\
\hline \multirow[t]{3}{*}{ Carbonyl (nmol/mg protein) } & IS & $1.08 \pm 0.041^{a}$ & $1.43 \pm 0.130^{a}$ & $2.47 \pm 0.291^{b}$ & $3.63 \pm 0.120^{c x}$ & $<.0001$ & 0.451 \\
\hline & GM & $1.09 \pm 0.010^{a}$ & $1.35 \pm 0.120^{a}$ & $2.50 \pm 0.122^{b}$ & $3.01 \pm 0.221^{c y}$ & $<.0001$ & \\
\hline & $P$ value & 0.231 & 0.154 & 0.347 & 0.035 & & \\
\hline \multirow[t]{3}{*}{ Free thiol (nmol/mg protein) } & is & $52.89 \pm 1.671^{\mathrm{a}}$ & $49.75 \pm 1.302^{\mathrm{a}}$ & $45.91 \pm 1.380^{\mathrm{b}}$ & $39.25 \pm 1.711^{c}$ & 0.014 & 0.234 \\
\hline & GM & $55.82 \pm 1.220^{\mathrm{a}}$ & $52.86 \pm 1.112^{\mathrm{a}}$ & $48.00 \pm 1.091^{\mathrm{b}}$ & $41.01 \pm 1.000^{c}$ & 0.021 & \\
\hline & $P$ value & 0.213 & 0.437 & 0.815 & 0.200 & & \\
\hline
\end{tabular}

$\overline{\mathrm{a}, \mathrm{b} c}$ means having different superscripts along the same row are significantly different $(P<0.05) .{ }^{x, y}$ means with different superscript along the same column are significantly different $(P<0.05)$. ${ }^{1}$ catalase activity is expressed as $n m o l . \mathrm{H}_{2} \mathrm{O}_{2} / \mathrm{min} / \mathrm{mg}$ protein. ${ }^{2}$ superoxide dismutase is expressed as the amount of enzyme needed to inhibit $50 \%$ dismutation of the superoxide radical. ${ }^{3}$ glutathione peroxidase activity is expressed as nmoles $\mathrm{NADPH}$ oxidized/min/mg protein

muscle type and chill storage was not significant for antioxidant enzyme activities in goat meat. The increase in the activities of CAT and SOD in oxidative muscles could be due to a positive feedback mechanism in response to rising oxidative deteriorations $[4,8]$.

Muscle type had no effect on the concentration of carotenoid, $\alpha, \gamma$ and $\delta$-tocopherol. In contrast, levels of $\alpha$-tocopherol were found to be highest in beef psoas major and gluteus medius and lowest in longissimus thoracis and longissimus lumborum while moderate levels of $\alpha$-tocopherol occurred in semimembranosus [56]. There was a decline $(P<0.05)$ in the concentration of carotenoid, $\alpha$, and $\gamma$-tocopherol as storage progressed. This finding is consistent with that of Irie et al. [57] who observed a reduction in the concentration of $\alpha$-tocopherol in Japanese beef as postmortem storage progressed. There was no significant interaction between muscle type and postmortem ageing for the concentration of tocopherols and total carotenoids in goat meat. The concentration of tocopherols and total carotenoids was correlated (data not shown) with indicators of quality deterioration in goat meat. This suggests that the tocopherol and carotenoids 
may be the primary driver for postmortem oxidative stability of goat meat.

\section{Lipid oxidation}

The effect of postmortem storage on lipid oxidation measured as thiobarbituric acid reactive substance (TBARS) is shown in Table 3. There was an increase $(P<0.05)$ in TBARS values in both muscles as postmortem storage progressed. This observation is consistent with findings in broiler meat $[58,59]$, beef $[4,12]$ and chevon $[9,15]$. Despite the increase in TBARS over storage, the range of TBARS values observed in the current study was below the threshold $(0.6 \mathrm{mg} \mathrm{MDA} / \mathrm{kg}$ ) specified for abnormal flavour development in meat [60].

Muscle type had no effect $(P<0.05)$ on TBARS value throughout storage. This could be due to the similar concentration of carotenoid and tocopherol in the muscles. In contrast, Renerre et al. [4] observed that diaphragma and psoas major had higher TBARS values compared with longissimus lumborum and tensor fasciae latae during an $8 \mathrm{~d}$ postmortem storage of beef. In turkey, Renerre et al. [8] observed that sartorius muscle had higher TBARS value than pectoralis major muscle during a $9 \mathrm{~d}$ postmortem ageing. The interaction between muscle type and postmortem chill storage was not significant for TBARS values in goat meat.

\section{Free thiol content}

The oxidation of accessible free thiol (the sulfhydryl group) from cysteine residues corresponds to the loss of thiols [31]. Postmortem chill storage had a significant $(P<$ $0.05)$ effect on the free thiol content in goat meat. The thiol concentration reduced from 52.89 to $39.25 \mathrm{nmol} / \mathrm{mg}$ protein in IS which represented a $26 \%$ reduction while in the GM, free thiol reduced from 55.82 to $41.01 \mathrm{nmol} / \mathrm{mg}$ protein, which represented a $27 \%$ reduction. Similarly, Petron et al. [16] observed about $23 \%$ loss of thiol groups in mutton from 4 to $8 \mathrm{~d}$ postmortem. Muscle type had no effect on free thiol content. In contrast, Mercier et al. [53] observed lower free thiol in oxidative sartorius than glycolytic pectoralis major of turkey meat during a $9 \mathrm{~d}$ postmortem chill storage. There was no significant interaction between the muscle type and chill storage for thiol concentration in goat meat.

\section{Carbonyl content}

The formation of carbonyl is one of the most significant chemical modifications of oxidized proteins $[4,14,16]$. The carbonyl content of goat meat increased $(P<0.05)$ over storage. This observation is akin to findings in beef $[4]$ turkey [8] and lamb $[14,16]$. The IS had higher $(P<$ 0.05 ) carbonyl content than GM on d 7 postmortem. Similarly, Renerre et al. [8] observed a higher carbonyl content in oxidative sartorius muscle than glycolytic pectoralis major muscle during a $9 \mathrm{~d}$ postmortem chill storage of turkey. In beef, Renerre et al. [4] observed greater carbonyl content in diaphragma muscle than longissimus dorsi muscle. In contrast, Martinaud et al. [61] observed a higher carbonyl content in longissimus lumborum compared with diaphragma pedialis of beef during a $10 \mathrm{~d}$ chill storage. There was no significant interaction between the muscle type and chill storage for carbonyl concentration in goat meat.

\section{Distribution of myofibrillar proteins}

A representative gel showing the SDS-PAGE of myofibrillar protein pattern in IS and GM muscles in goats during chill storage is shown in Fig. 1. A representative WesternBlots of slow MHC, fast MHC and actin in IS and GM muscles in goats during chill storage is shown in Fig. 2. Table 4 shows the reflective density of myofibrillar proteins in IS and GM muscles during postmortem chill storage.

The Western-blot analysis and the reflective band intensity showed that the IS had greater $(P<0.05)$ reflective density of slow MHC than GM throughout storage. In contrast, the western blots and reflective density of fast MHC and actin were greater $(P<0.05)$ in GM compared with IS throughout storage. This finding was expected and it relates to the differences in the biochemical and functional properties of muscle fibres in the muscles. The greater fast MHC and actin in GM muscle reflects its function as a white/glycolytic muscle used for short and rapid contractions $[1,17,18]$. The greater slow MHC in IS indicates its function as a red/oxidative muscle used to carry out slow and sustained contraction for prolonged period without fatigue $[1,17,18]$. The current distribution pattern of myofibrillar protein is consistent with those of Sazili et al. [25] who found that the level of slow MHC in supraspinatus was significantly greater than that of longissimus lumborum and semitendinosus muscles in sheep. In addition, the fast MHC content in longissimus lumborum and semitendinosus muscles was greater than that of supraspinatus muscle in sheep [25]. Postmortem chill storage had no effect $(P>0.05)$ on the distribution of myofibrillar proteins in goat meat.

\section{Degradation of myofibrillar proteins}

Chill storage had a significant effect $(P<0.05)$ on the SDS-PAGE patterns, western blots, reflective density and \% loss of fast MHC and slow MHC in goat meat. Regardless of muscle, the western blots and the reflective density of slow MHC and fast MHC decreased $(P<0.05)$ over storage. The degradation of MHC over storage is consistent with findings in camel meat [62], chevon [63] and rabbit meat [64]. In contrast, Bandman and Zdanis [65] posited that myosin was resilient after $28 \mathrm{~d}$ postmortem ageing of beef at $4{ }^{\circ} \mathrm{C}$. In addition, the MHC in 


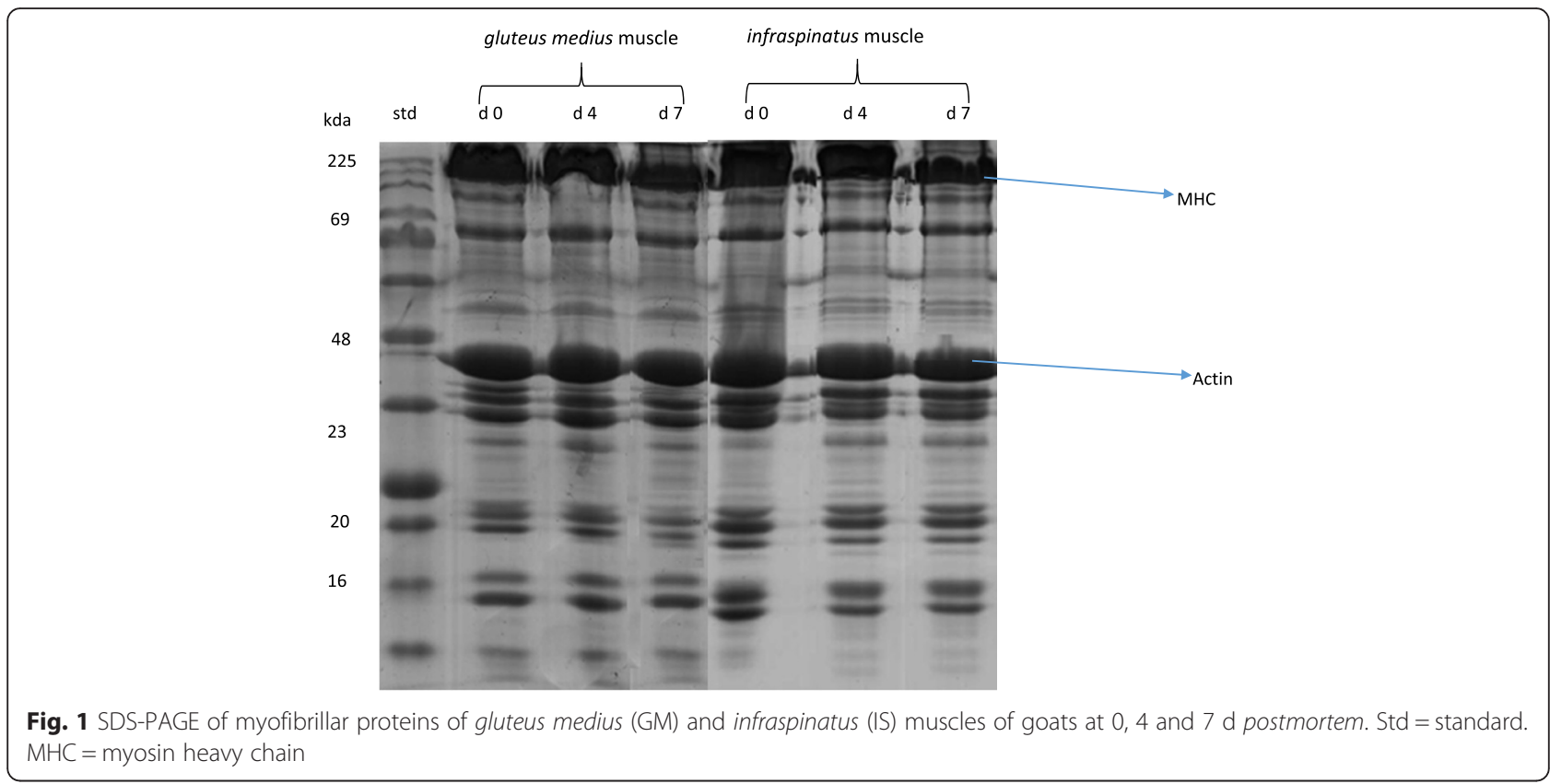

rabbit meat did not degrade during a $7 \mathrm{~d}$ postmortem ageing [66].

The percentage loss (degradation) of fast MHC was greater $(P<0.05)$ in IS than GM on $\mathrm{d} 4$ and 7 postmortem. Similarly, the degradation of slow MHC was greater $(P<0.05)$ in IS than GM on $\mathrm{d} 7$ postmortem. This observation is consistent with the greater carbonyl content in IS compared with GM on day 7 postmortem. Oxidative muscles contain greater concentration of free iron than glycolytic muscles, and the free iron could catalyse the oxidative degradation of proteins $[1,4,8]$.

Postmortem ageing did not affect $(P>0.05)$ the reflective density of actin in IS and GM muscles in goats. Similarly, actin underwent little or no degradation when rabbit meat $[64,66]$ and chevon [64] were subjected to chill storage. In contrast, actin was degraded during a 9 $\mathrm{d}$ chill storage of camel meat [62].

\section{Intramuscular fat and fatty acid composition}

The fatty acid (FA) composition and intramuscular fat (IMF) of IS and GM muscles subjected to postmortem chill storage is shown in Table 5 . The IS muscle had higher $(P<0.05)$ IMF compared with GM. High IMF is a known characteristic of oxidative muscles which suggests the need to meet the high energy demand for cellular metabolisms by fat oxidation $[67,68]$. Similarly, oxidative triceps brachiii had greater intramuscular fat than glycolytic gluteus medius in grass-fed beef [68].

The major fatty acids in the muscles were C18:1n-9, C18:0 and C16:0. Similar findings were observed in beef

Fig. 2 A representative Western- Blots of slow myosin heavy chain, fast myosin heavy chain and actin in infraspinatus and gluteus medius muscle
in goats during postmortem chill storage


Table 4 Reflective density of myofibrillar proteins in infraspinatus (IS) and gluteus medius (GM) muscles in goats during postmortem chill storage

\begin{tabular}{|c|c|c|c|c|c|c|}
\hline \multirow[b]{2}{*}{ Parameter } & \multirow[b]{2}{*}{ Muscle } & \multicolumn{3}{|c|}{ Storage time (days) } & \multicolumn{2}{|c|}{$P$ value } \\
\hline & & 0 & 4 & 7 & Storage & Storage $\times$ muscle \\
\hline \multirow[t]{3}{*}{ Fast $\mathrm{MHC}^{1}$ (density $/ \mathrm{mm}^{2}$ ) } & IS & $26.54 \pm 0.120^{\mathrm{ax}}$ & $23.00 \pm 0.209^{\mathrm{bx}}$ & $20.49 \pm 0.231^{c x}$ & 0.004 & 0.091 \\
\hline & GM & $94.33 \pm 0.100^{\text {ay }}$ & $88.44 \pm 0.707^{\text {by }}$ & $81.20 \pm 0.309^{c y}$ & 0.023 & \\
\hline & $P$ value & 0.001 & 0.002 & 0.001 & & \\
\hline \multirow[t]{3}{*}{$\%$ loss of fast MHC } & IS & & $13.33 \pm 0.900^{\text {by }}$ & $22.61 \pm 2.110^{\text {ay }}$ & 0.009 & 0.09 \\
\hline & GM & & $6.24 \pm 0.001^{b x}$ & $13.91 \pm 0.148^{\mathrm{ax}}$ & 0.012 & \\
\hline & $P$ value & & 0.021 & 0.033 & & \\
\hline \multirow[t]{3}{*}{ Slow $M H C^{1}$ (density $/ \mathrm{mm}^{2}$ ) } & IS & $100.01 \pm 4.011^{\mathrm{ay}}$ & $85.00 \pm 2.991^{\text {by }}$ & $63.44 \pm 3.311^{c y}$ & 0.001 & 0.102 \\
\hline & GM & $24.10 \pm 0.122^{\mathrm{ax}}$ & $20.30 \pm 2.00^{\mathrm{bx}}$ & $17.00 \pm 2.121^{c x}$ & 0.001 & \\
\hline & $P$ value & 0.009 & 0.011 & 0.001 & & \\
\hline \multirow[t]{3}{*}{$\%$ loss of slow MHC } & is & & $15.00 \pm 0.020^{b}$ & $36.56 \pm 2.067^{\text {ay }}$ & 0.032 & 0.110 \\
\hline & GM & & $15.76 \pm 0.341^{b}$ & $29.16 \pm 2.019^{\mathrm{ax}}$ & 0.016 & \\
\hline & $P$ value & & 0.130 & 0.002 & & \\
\hline \multirow[t]{3}{*}{ Actin (density/mm²) } & is & $13.76 \pm 0.400^{x}$ & $13.50 \pm 1.207^{x}$ & $13.40 \pm 0.610^{x}$ & 0.100 & 0.102 \\
\hline & GM & $21.00 \pm 0.211^{y}$ & $20.69 \pm 0.144^{y}$ & $20.50 \pm 0.201^{y}$ & 0.120 & \\
\hline & $P$ value & 0.009 & 0.021 & 0.018 & & \\
\hline \multirow[t]{3}{*}{$\%$ loss of actin } & IS & & $1.16 \pm 0.001$ & $2.61 \pm 0.863$ & 0.091 & 0.087 \\
\hline & GM & & $1.47 \pm 0.001$ & $2.38 \pm 0.152$ & 0.070 & \\
\hline & $P$ value & & 0.114 & 0.185 & & \\
\hline
\end{tabular}

a, b c means having different superscripts along the same row are significantly different $(P<0.05) .{ }^{x, y}$ means with different superscript along the same column are significantly different $(P<0.05)$. 1 myosin heavy chain

[68], chevon [69] and mutton [70]. Muscle type had no effect $(P>0.05)$ on the FA composition. However, GM had lower $(P<0.05) \mathrm{n} 6 / \mathrm{n} 3$ ratio than IS throughout storage. Postmortem chill storage had a significant $(P<0.05)$ impact on the concentration of some FA in both muscles. The concentration of all n-3 and n-6 FA, and total polyunsaturated fatty acids (PUFA) decreased $(P<0.05)$ while the concentration of individual saturated fatty acids (SFA) and total SFA increased $(P<0.05)$ as storage progressed. This observation concurs with that of Muíño et al. [70] who observed a decrease in the concentration of $n-3$ and $n-6$ PUFA in mutton aged for $12 \mathrm{~d}$. Similarly, the concentration of n-3 and n-6 FA decreased during a $7 \mathrm{~d}$ chilled storage of mutton [71]. Except C16:1n-7 and C17:1 whose concentration increased $(P<0.05)$ over storage, most monounsaturated fatty acids (MUFA) were unaffected $(P>0.05)$ by postmortem chill storage. The instability of PUFA coincides with the increase in TBARS values and the reduction in the concentration of carotenoid and tocopherol as storage progressed. The reduction in the concentration of PUFA was responsible for the increment in the concentration of SFA. The concentration of CLA cis-9 trans-11 and CLA trans-10 cis-12 and total MUFA was stable $(P>0.05)$ throughout storage. This indicates that CLA and MUFA have less propensity to oxidize compared with PUFA. There was no significant interaction between muscle type and postmortem chill storage for IMF and fatty acid composition of goat meat.

\section{Conclusion}

The results of this study evince that changes in meat quality during postmortem chill storage is inexorable. However, muscles differ in their response to postmortem chill storage. The IS muscle had higher redness and lower cooking loss on $\mathrm{d} 0$ and 1 , and lower shear force on d 0, 1 and 4 than GM. However, IS had greater drip loss, carbonyl content, MHC degradation and colour deterioration than GM on d 7. The greater SOD and CAT activities in IS suggests a feedback mechanism in response to the greater oxidative deterioration. The GM had lower colour deterioration and MHC degradation and thus suitable for chilled storage for longer periods. The MHC and colour of IS could be maintained for up to 4 days of postmortem chill storage. The tocopherol and carotenoids seemed to be the primary drivers for postmortem oxidative stability of goat meat during chill storage. Further study to examine the effect of postmortem chill storage for extended periods on the antioxidant status, degradation of myofibrillar proteins, physicochemical properties and microbiological quality of different muscles in goat is suggested. 
Table 5 Intramuscular fat (mg/100 g) and fatty acid composition (\% of total fatty acid) of infraspinatus (IS) and gluteus medius (GM) muscles in goats during postmortem chill storage

\begin{tabular}{|c|c|c|c|c|c|c|}
\hline \multirow[b]{2}{*}{ Parameter } & \multirow[b]{2}{*}{ Muscle } & \multicolumn{3}{|c|}{ Storage time (days) } & \multicolumn{2}{|c|}{$P$ value } \\
\hline & & $\overline{0}$ & 4 & 7 & Storage & Muscle $\times$ storage \\
\hline \multirow[t]{3}{*}{$\mathrm{C} 12: 0$} & is & $0.26 \pm 0.010^{c}$ & $0.30 \pm 0.012^{b}$ & $0.34 \pm 0.010^{\mathrm{a}}$ & $<.0001$ & 0.219 \\
\hline & GM & $0.30 \pm 0.011^{b}$ & $0.32 \pm 0.021^{b}$ & $0.35 \pm 0.021^{a}$ & 0.013 & \\
\hline & $P$ value & 0.122 & 0.221 & 0.191 & & \\
\hline \multirow[t]{3}{*}{ C14:0 } & IS & $1.89 \pm 0.021^{c}$ & $2.00 \pm 0.010^{b}$ & $2.14 \pm 0.020^{\mathrm{a}}$ & 0.001 & 0.130 \\
\hline & GM & $1.98 \pm 0.010^{b}$ & $2.12 \pm 0.010^{a}$ & $2.14 \pm 0.010^{a}$ & 0.011 & \\
\hline & $P$ value & 0.110 & 0.210 & 0.923 & & \\
\hline \multirow[t]{3}{*}{ C14:1 } & is & $0.10 \pm 0.010$ & $0.09 \pm 0.011$ & $0.10 \pm 0.010$ & 0.429 & 0.213 \\
\hline & GM & $0.12 \pm 0.121$ & $0.11 \pm 0.120$ & $0.12 \pm 0.110$ & 0.500 & \\
\hline & $P$ value & 0.712 & 0.115 & 0.345 & & \\
\hline \multirow[t]{3}{*}{$\mathrm{C} 15: 0$} & is & $0.54 \pm 0.021^{c}$ & $0.65 \pm 0.020^{b}$ & $0.80 \pm 0.040^{a}$ & $<.0001$ & 0.143 \\
\hline & GM & $0.60 \pm 0.011^{b}$ & $0.64 \pm 0.031^{b}$ & $0.75 \pm 0.011^{a}$ & 0.014 & \\
\hline & $P$ value & 0.201 & 0.345 & 0.167 & & \\
\hline \multirow[t]{3}{*}{ C15:1 } & IS & $0.60 \pm 0.009^{a}$ & $0.60 \pm 0.012^{a}$ & $0.70 \pm 0.010^{b}$ & 0.041 & \\
\hline & GM & $0.65 \pm 0.008^{\mathrm{a}}$ & $0.67 \pm 0.012^{\mathrm{a}}$ & $0.72 \pm 0.011^{b}$ & 0.020 & 0.230 \\
\hline & $P$ value & 0.144 & 0.125 & 0.223 & & \\
\hline \multirow[t]{3}{*}{$\mathrm{C} 16: 0$} & IS & $19.20 \pm 0.210^{c}$ & $20.97 \pm 0.310^{b}$ & $21.22 \pm 0.667^{\mathrm{a}}$ & $<.0001$ & 0.331 \\
\hline & GM & $19.41 \pm 0.112^{c}$ & $20.44 \pm 0.121^{b}$ & $21.10 \pm 0.325^{a}$ & 0.003 & \\
\hline & $P$ value & 0.221 & 0.298 & 0.145 & & \\
\hline \multirow[t]{3}{*}{ C16:1n-7 } & is & $1.20 \pm 0.021^{b}$ & $1.79 \pm 0.061^{\mathrm{a}}$ & $1.75 \pm 0.027^{\mathrm{a}}$ & $<.0001$ & \\
\hline & GM & $1.98 \pm 0.010^{b}$ & $2.30 \pm 0.020^{a}$ & $2.33 \pm 0.089^{a}$ & 0.042 & 0.219 \\
\hline & $P$ value & 0.191 & 0.063 & 0.061 & & \\
\hline \multirow[t]{3}{*}{$\mathrm{C} 17: 0$} & is & $0.62 \pm 0.036^{b}$ & $0.64 \pm 0.020^{b}$ & $0.74 \pm 0.021^{a}$ & 0.017 & \\
\hline & GM & $0.71 \pm 0.017^{b}$ & $0.74 \pm 0.010^{b}$ & $0.80 \pm 0.041^{a}$ & 0.042 & 0.117 \\
\hline & $P$ value & 0.129 & 0.212 & 0.156 & & \\
\hline \multirow[t]{3}{*}{ C17:1 } & IS & $0.41 \pm 0.010^{b}$ & $0.65 \pm 0.023^{a}$ & $0.70 \pm 0.021^{\mathrm{a}}$ & $<.0001$ & \\
\hline & GM & $0.43 \pm 0.011^{c}$ & $0.59 \pm 0.012^{b}$ & $0.73 \pm 0.012^{\mathrm{a}}$ & $<.0001$ & 0.127 \\
\hline & $P$ value & 0.110 & 0.201 & 0.120 & & \\
\hline \multirow[t]{3}{*}{ C18:0 } & IS & $20.21 \pm 0.450^{c}$ & $21.25 \pm 0.300^{b}$ & $22.50 \pm 0.561^{a}$ & 0.031 & \\
\hline & GM & $20.41 \pm 0.210^{c}$ & $22.01 \pm 0.110^{b}$ & $23.21 \pm 0.472^{a}$ & 0.042 & 0.222 \\
\hline & $P$ value & 0.161 & 0.540 & 0.07 & & \\
\hline \multirow[t]{3}{*}{ C18:1n-9 } & IS & $27.52 \pm 0.705$ & $27.07 \pm 0.209$ & $27.09 \pm 0.767$ & 0.142 & \\
\hline & GM & $26.23 \pm 0.338$ & $26.14 \pm 0.217$ & $28.24 \pm 0.189$ & 0.213 & 0.223 \\
\hline & $P$ value & 0.649 & 0.136 & 0.598 & & \\
\hline \multirow[t]{3}{*}{ C18:1 t-11 } & IS & $1.60 \pm 0.021$ & $1.65 \pm 0.022$ & $1.64 \pm 0.010$ & 0.117 & \\
\hline & GM & $1.64 \pm 0.012$ & $1.56 \pm 0.051$ & $1.67 \pm 0.051$ & 0.238 & 0.192 \\
\hline & $P$ value & 0.190 & 0.167 & 0.221 & & \\
\hline \multirow[t]{3}{*}{ CLA cis-9 trans-11 } & IS & $0.90 \pm 0.011$ & $0.92 \pm 0.011$ & $0.90 \pm 0.012$ & 0.142 & \\
\hline & GM & $0.93 \pm 0.051$ & $0.96 \pm 0.032$ & $0.94 \pm 0.043$ & 0.134 & 0.219 \\
\hline & $P$ value & 0.141 & 0.132 & 0.113 & & \\
\hline \multirow[t]{2}{*}{ CLA trans-10 cis-12 } & is & $0.90 \pm 0.038$ & $0.89 \pm 0.005$ & $0.91 \pm 0.021$ & 0.195 & \\
\hline & GM & $0.82 \pm 0.016$ & $0.84 \pm 0.006$ & $0.85 \pm 0.048$ & 0.175 & 0.223 \\
\hline
\end{tabular}


Table 5 Intramuscular fat (mg/100 g) and fatty acid composition (\% of total fatty acid) of infraspinatus (IS) and gluteus medius (GM) muscles in goats during postmortem chill storage (Continued)

\begin{tabular}{|c|c|c|c|c|c|c|}
\hline & $P$ value & 0.100 & 0.213 & 0.163 & & \\
\hline \multirow[t]{3}{*}{ C18:2n-6 } & IS & $13.25 \pm 0.120^{\mathrm{a}}$ & $12.00 \pm 0.110^{b}$ & $11.05 \pm 0.761^{c}$ & $<.0001$ & \\
\hline & GM & $12.06 \pm 0.140^{\mathrm{a}}$ & $11.09 \pm 0.120^{b}$ & $10.21 \pm 0.111^{c}$ & 0.034 & 0.145 \\
\hline & $P$ value & 0.223 & 0.154 & 0.170 & & \\
\hline \multirow[t]{3}{*}{$C 18: 3 n-3$} & IS & $2.00 \pm 0.050^{a}$ & $1.53 \pm 0.030^{b}$ & $1.02 \pm 0.010^{c}$ & $<.0001$ & \\
\hline & GM & $1.98 \pm 0.020^{\mathrm{a}}$ & $1.64 \pm 0.010^{b}$ & $1.21 \pm 0.031^{c}$ & $<.0001$ & 0.134 \\
\hline & $P$ value & 0.210 & 0.130 & 0.230 & & \\
\hline \multirow[t]{3}{*}{$C 20: 4 n-6$} & IS & $5.40 \pm 0.111^{a}$ & $4.47 \pm 0.115^{b}$ & $4.38 \pm 0.091^{b}$ & $<.0001$ & \\
\hline & GM & $5.19 \pm 0.132^{a}$ & $4.60 \pm 0.119^{b}$ & $4.00 \pm 0.145^{c}$ & $<.0001$ & 0.145 \\
\hline & $P$ value & 0.101 & 0.219 & 0.231 & & \\
\hline \multirow[t]{3}{*}{$C 20: 5 n-3$} & IS & $1.11 \pm 0.010^{\mathrm{a}}$ & $1.02 \pm 0.020^{\mathrm{ab}}$ & $0.78 \pm 0.031^{b}$ & $<.0001$ & 0.250 \\
\hline & GM & $1.40 \pm 0.021^{\mathrm{a}}$ & $1.37 \pm 0.030^{\mathrm{a}}$ & $1.02 \pm 0.012^{b}$ & 0.024 & \\
\hline & $P$ value & 0.142 & 0.133 & 0.212 & & \\
\hline \multirow[t]{3}{*}{$C 22: 5 n-3$} & IS & $1.20 \pm 0.041^{a}$ & $1.00 \pm 0.010^{b}$ & $0.90 \pm 0.020^{c}$ & 0.041 & \\
\hline & GM & $1.31 \pm 0.022^{a}$ & $1.03 \pm 0.020^{b}$ & $1.00 \pm 0.031^{c}$ & 0.023 & 0.461 \\
\hline & $P$ value & 0.072 & 0.221 & 0.090 & & \\
\hline \multirow[t]{3}{*}{$C 22: 6 n-3$} & IS & $0.90 \pm 0.010^{\mathrm{a}}$ & $0.80 \pm 0.022^{b}$ & $0.75 \pm 0.005^{b}$ & $<.0001$ & \\
\hline & GM & $0.91 \pm 0.021^{a}$ & $0.83 \pm 0.021^{b}$ & $0.72 \pm 0.008^{c}$ & 0.004 & 0.220 \\
\hline & $P$ value & 0.221 & 0.316 & 0.145 & & \\
\hline \multirow[t]{3}{*}{ Intramuscular fat (mg/100 g) } & IS & $3030.23 \pm 20.231^{y}$ & $3100.15 \pm 30.001^{y}$ & $3050.00 \pm 20.331^{y}$ & 0.110 & \\
\hline & GM & $2880.90 \pm 10.122^{x}$ & $2840.69 \pm 20.450^{x}$ & $2890.21 \pm 15.211^{x}$ & 0.108 & 0.211 \\
\hline & $P$ value & 0.042 & 0.040 & 0.041 & & \\
\hline \multirow[t]{3}{*}{$\Sigma$ SFA } & IS & $42.72 \pm 0.451^{c}$ & $45.81 \pm 0.141^{b}$ & $47.74 \pm 0.332^{a}$ & $<.0001$ & \\
\hline & GM & $43.41 \pm 0.230^{c}$ & $46.27 \pm 0.220^{b}$ & $48.35 \pm 0.331^{\mathrm{a}}$ & 0.001 & 0.112 \\
\hline & $P$ value & 0.126 & 0.327 & 0.114 & & \\
\hline \multirow[t]{3}{*}{$\sum$ MUFA } & IS & $31.43 \pm 0.110$ & $31.85 \pm 0.420$ & $31.98 \pm 0.610$ & 0.212 & \\
\hline & GM & $32.00 \pm 0.191$ & $31.37 \pm 0.291$ & $32.14 \pm 0.171$ & 0.450 & 0.341 \\
\hline & $P$ value & 0.116 & 0.221 & 0.145 & & \\
\hline \multirow[t]{3}{*}{$\Sigma$ PUFA } & IS & $25.66 \pm 0.547^{\mathrm{a}}$ & $22.73 \pm 0.219^{b}$ & $20.69 \pm 0.425^{c}$ & 0.001 & \\
\hline & GM & $24.60 \pm 0.226^{a}$ & $22.36 \pm 0.137^{b}$ & $19.95 \pm 0.289^{c}$ & 0.012 & 0.217 \\
\hline & $P$ value & 0.112 & 0.651 & 0.231 & & \\
\hline \multirow[t]{3}{*}{$\sum n-3$} & IS & $5.21 \pm 0.021^{a}$ & $4.35 \pm 0.017^{b}$ & $3.45 \pm 0.011^{c}$ & 0.004 & \\
\hline & GM & $5.60 \pm 0.050^{a}$ & $4.87 \pm 0.018^{b}$ & $3.95 \pm 0.010^{c}$ & 0.001 & 0.431 \\
\hline & $P$ value & 0.230 & 0.112 & 0.349 & & \\
\hline \multirow[t]{3}{*}{$\sum n-6$} & IS & $18.65 \pm 0.292^{a}$ & $16.57 \pm 0.440^{b}$ & $15.43 \pm 0.115^{c}$ & 0.001 & \\
\hline & GM & $17.25 \pm 0.451^{a}$ & $15.69 \pm 0.225^{b}$ & $14.21 \pm 0.389^{c}$ & 0.003 & 0.144 \\
\hline & $P$ value & 0.932 & 0.238 & 0.476 & & \\
\hline \multirow[t]{3}{*}{$n-6: n-3$} & IS & $3.57 \pm 0.011^{c y}$ & $3.80 \pm 0.017^{\text {by }}$ & $4.47 \pm 0.016^{\mathrm{ay}}$ & 0.001 & 0.221 \\
\hline & GM & $3.08 \pm 0.022^{c x}$ & $3.22 \pm 0.008^{b x}$ & $3.59 \pm 0.025^{\mathrm{ax}}$ & 0.001 & \\
\hline & $P$ value & 0.045 & 0.032 & 0.023 & & \\
\hline
\end{tabular}


Table 5 Intramuscular fat (mg/100 g) and fatty acid composition (\% of total fatty acid) of infraspinatus (IS) and gluteus medius (GM) muscles in goats during postmortem chill storage (Continued)

\begin{tabular}{|c|c|c|c|c|c|c|}
\hline \multirow[t]{3}{*}{ UFA:SFA } & IS & $1.34 \pm 0.017$ & $1.19 \pm 0.010$ & $1.10 \pm 0.007$ & 0.779 & 0.100 \\
\hline & GM & $1.33 \pm 0.028$ & $1.16 \pm 0.020$ & $1.08 \pm 0.039$ & 0.174 & \\
\hline & $P$ value & 0.212 & 0.661 & 0.132 & & \\
\hline \multirow[t]{3}{*}{ PUFA:SFA } & IS & $0.60 \pm 0.016^{a}$ & $0.49 \pm 0.010^{b}$ & $0.43 \pm 0.020^{c}$ & 0.009 & \\
\hline & GM & $0.56 \pm 0.028^{a}$ & $0.47 \pm 0.030^{b}$ & $0.41 \pm 0.010^{c}$ & 0.032 & 0.109 \\
\hline & $P$ value & 0.142 & 0.182 & 0.112 & & \\
\hline
\end{tabular}

a, b, c means having different superscript along the same row are significantly different $(P<0.05) .{ }^{x, y}$ means having different superscript along the same column are significantly different $(P<0.05) . \Sigma$ SFA $=(C 14: 0+C 15: 0+C 16: 0+C 17: 0+C 18: 0), \Sigma$ MUFA $=(C 14: 1+C 15: 1+C 16: 1+C 17: 1+C 18: 1+C 18: 1$ trans-11),

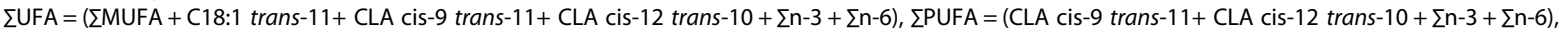
$\sum n-3=(C 18: 3 n-3+C 20: 5 n-3+C 22: 5 n-3+C 22: 6 n-3), \sum n-6=(C 18: 2 n-6+C 20: 4 n-6) n-6: n-3=(C 18: 2 n-6+C 20: 4 n-6) \div(C 18: 3 n-3+C 20: 5 n-3+C 22: 5 n-3+C 22: 6 n-3)$, UFA:SFA $=(\Sigma U F A) / \Sigma S F A)$, PUFA:SFA $=(\Sigma P U F A / \Sigma S F A)$

\section{Competing interest}

The authors declare that they have no competing interest.

\section{Authors' contribution}

KDA, RK, SAK and AQS conceived the idea. KDA, AQS, RMS, RK, AAA and ABS did the meat quality, fatty acid and antioxidant analysis. KDA, ABS, SAK and AAA did the SDS-PAGE. KDA, RK and RMS did the sensory analysis. KDA prepared the manuscript and did the statistical analysis. All authors read and approved the manuscript.

\section{Author details}

${ }^{1}$ Department of Animal Science, Faculty of Agriculture, Universiti Putra Malaysia, 43400 UPM Serdang, Selangor, Malaysia. ${ }^{2}$ Department of Food Technology, Faculty of Food Science and Technology, Universiti Putra Malaysia, 43400 UPM Serdang, Selangor, Malaysia. ${ }^{3}$ Halal Products Research Institute, Universiti Putra Malaysia, 43400 UPM Serdang, Selangor, Malaysia. ${ }^{4}$ Laboratory of Animal Production, Institute of Tropical Agriculture, Universiti Putra Malaysia, 43400 UPM Serdang, Selangor, Malaysia. ${ }^{5}$ Department of Animal Production, University of Ilorin, PMB 1515 Ilorin, Nigeria. ${ }^{6}$ Department of Animal Resource, University of Salahaddin, Erbil, Kurdistan Region, Iraq. ${ }^{7}$ Institute of Biological Sciences, Faculty of Science, University of Malaya, Kuala Lumpur, Malaysia.

Received: 5 December 2015 Accepted: 7 May 2016 Published online: 15 June 2016

\section{References}

1. Lawrie R, Ledward D. Lawrie's meat science. Cambridge: Woodhead Publishing Ltd.; 2006.

2. Farouk M, Mustafa NM, Wu G, Krsinic G. The "sponge effect" hypothesis: An alternative explanation of the improvement in the water holding capacity of meat with ageing. Meat Sci. 2012;90:670-7.

3. Astruc T, Marinova P, Labas R, Gatellier P, Sant'e-Lhoutellier V. Detection and localization of oxidized proteins in muscle cells by fluorescence microscopy. J Agric Food Chem. 2007;55:9554-8.

4. Renerre M, Dumont F, Gatellier P. Antioxidant enzyme activities in beef in relation to oxidation of lipid and myoglobin. Meat Sci. 1996;43:111-21.

5. Rowe L, Maddock K, Lonergan SM, Huff-Lonergan E. Influence of early postmortem protein oxidation on beef quality. J Anim Sci. 2004;82:785-93.

6. Sola-Ojo FE, Adeyemi KD, Toye AA, Bolu SA, Fayeye TR, Annongu A, Garba SO, Karim RO. Performance, carcass profile and oxidative stability of broiler chickens fed processed baobab seed meal. Bull Environ Pharmaco Life Sci. 2013;2:94-9.

7. Kanner J. Dietary advanced lipid oxidation endproducts are risk factors to human health. Molecular nutrition \& food research. 2007;51:1094-101.

8. Renerre M, Poncet $K$, Mercier Y, Gatellier P, Métro B. Influence of dietary fat and vitamin $E$ on antioxidant status of muscles of turkey. J Agr Food Chem. 1999;47:237-44.

9. Karami M, Alimon AR, Sazili AQ, Goh YM, Ivan M. Effects of dietary antioxidants on the quality, fatty acid profile, and lipid oxidation of longissimus muscle in Kacang goat with aging time. Meat Sci. 2011;88:102-8.
10. Xiong YL. Protein oxidation and implications for muscle food quality. In: Decker EA, Cameron Faustman C, Lopez-Bote CJ, editors. Antioxidants in Muscle Foods: Nutritional Strategies to Improve Quality. New York: Wiley and Sons; 2000. p. 85-90.

11. Bekhit A, Geesink G, llian M, Morton J, Bickerstaffe R. The effects of natural antioxidants on oxidative processes and metmyoglobin reducing activity in beef patties. Food Chem. 2003;81:175-87.

12. Liu F, Xu Q, Dai R. Ni Y (2015). Effects of natural antioxidants on colour stability, lipid oxidation and metmyoglobin reducing activity in raw beef patties. Acta Sci. Pol. Technol. Aliment. 2015;14:37-44.

13. Bekhit A, Geesink G, Morton J, Bickerstaffe R. Metmyoglobin reducing activity and colour stability of ovine longissimus muscle. Meat Sci. 2001;57:427-35.

14. Santé-Lhoutellier V, Engel E, Aubry L, Gatellier P. Effect of animal (lamb) diet and meat storage on myofibrillar protein oxidation and in vitro digestibility. Meat Sci. 2008;79:777-83.

15. Sabow AQ, Sazili AQ, Zulkifli I, Goh YM, Ab Kadir MZA, Abdulla N, Nakyinsige K Kaka U, Adeyemi KD. A comparison of bleeding efficiency, microbiological quality and lipid oxidation in goats subjected to conscious halal slaughter and slaughter following minimal anesthesia. Meat Sci. 2015;104:78-84

16. Petron M, Raes K, Claeys E, Lourenço M, Fremaut D, De Smet S. Effect of grazing pastures of different botanical composition on antioxidant enzyme activities and oxidative stability of lamb meat. Meat Sci. 2007;75:737-45.

17. Reggiani C, Mascarello F. Fibre Type Identification and functional characterization in adult livestock animals. In: te Pas MFW, Everts ME, Haagsman HP, editors. Muscle development of livestock animals. Physiology, genetics and meat quality. Cambridge: CABI Publishing; 2004. p. 39-62.

18. Kirchofer K, Calkins CR, Gwartney B. Fiber-type composition of muscles of the beef chuck and round. J Anim Sci. 2002;80:2872-8.

19. Department of Standards, Malaysia. MS1500:2009: Halal food production, preparation, handling and storage-General guidelines (second revision) Malaysia. Cyberjaya: Department of Standards, Malaysia; 2009.

20. AMSA. AMSA Meat Color Measurement Guidelines. Champaign, IL, USA: American Meat Science Association; 2012.

21. Warriss PD. The extraction of haem pigments from fresh meat. J Food Tech. 1979;14:75-80.

22. Krzywicki K. The determination of haem pigments in meat. Meat Sci. 1982;7:29-36.

23. Mikkelsen A, Juncher D, Skibsted LH. Metmyoglobin reductase activity in porcine m. longissimus dorsi muscle. Meat Sci. 1999;51:155-61.

24. Sabow AB, Sazili AQ, Zulkifli I, Goh YM, Ab Kadir MZA, Adeyemi KD. Physico-chemical characteristics of longissimus lumborum muscle in goats subjected to halal slaughter and anesthesia (halothane) pre-slaughter. Anim Sci J. 2015. doi:10.1111/asj.12385.

25. Sazili AQ, Parr T, Sensky PL, Jones SW, Bardsley RG, Buttery PJ. The relationship between slow and fast myosin heavy chain content, calpastatin and meat tenderness in different ovine skeletal muscles. Meat Sci. 2005;69:17-25.

26. Meilgaard M, Civille GV, Carr BT. Sensory Evaluation Techniques. 4th ed. Bosta: CRC Press; 1637. p. 2007.

27. Adeyemi KD, Olorunsanya AO. Effect of tomato (lycopersicon esculentum) powder on oxidative stability and sensory characteristics of broiler meat. Afr J Food Agr Nutr Dev. 2012;12:6794-808. 
28. Kamal-Eldin A, Frank J, Razdan A, Tengblad S, Basu S, Vessby B. Effects of dietary phenolic compounds on tocopherol, cholesterol, and fatty acids in rats. Lipids. 2000;35:427-35.

29. Adeyemi KD, Sabow AB, Aghwan ZA, Ebrahimi M, Samsudin AA, Alimon AR et al. Serum fatty acids, biochemical indices and antioxidant status in goats fed canola oil and palm oil blend. J Anim Sci Technol. 2016;58:6.

30. Winterbourn CC. Oxidative reactions of hemoglobin. Method, Enzymol. 1990;186:265.

31. Morzel M, Gatellier P, Sayd T, Renerre M, Laville E. Chemical oxidation decreases proteolytic susceptibility of skeletal muscle myofibrillar proteins. Meat Sci. 2006;73:536-43.

32. Bradford MM. A rapid and sensitive method for the quantitation of microgram quantities of protein utilizing the principle of protein-dye binding. Analyt Biochem. 1976;72:248-54.

33. Adeyemi KD, Mislan N, Aghwan ZA, Sarah SA, Sazili AQ. Myofibrillar protein profile of Pectoralis major muscle in broiler chickens subjected to different freezing and thawing methods. Int Food Res J. 2014;21:1125-9.

34. Laemmli UK. Cleavage of structural proteins during the assembly of the head of bacteriophage T4. Nature. 1970;227:680-5.

35. Folch J, Lees M, Sloane-Stanley GA. Simple method for the isolation and purification of total lipids from animal tissues. J Biol Chem. 1957;226:497-509.

36. Rajion M, McLean J, Cahill RN. Essential fatty acids in the fetal and newborn lamb. Aust J Biol Sci. 1985;38:33-40.

37. AOAC. Official methods of analysis. 15th ed. Arlington, VA: Association of Official Analytical Chemists; 1990. p. 931-2.

38. Adeyemi KD, Sazili AQ, Ebrahimi M, Samsudin AA, Alimon AR, Karim R, et al. Effects of blend of canola oil and palm oil on nutrient intake and digestibility, growth performance, rumen fermentation and fatty acids in goats. Anim Sci J. 2015. doi:10.1111/asj.12549.

39. SAS. Statistical Analysis System package (SAS) Version 9.2 software. Cary, NC, USA: SAS Institute Inc; 2003.

40. Adeyemi KD, Sazili AQ. Efficacy of carcass electrical stimulation in meat quality enhancement: A review. Asian-Aust J Anim Sci. 2014;27:447-56.

41. Kadim I, Mahgoub O, Al-Ajmi D, Al-Maqbaly R, Al-Saqri N, Ritchie A. An evaluation of the growth, carcass and meat quality characteristics of Omani goat breeds. Meat Sci. 2004;66:203-10

42. Sitthigripong R, Sethakul J, Chaosap C. Meat characteristics among four muscle types of crossbred Boer goat. Poster session presented at: The Power of Meat in 21st Century. 59th International Congress of Meat Science and Technology, Izmir, Turkey. 2013; S5-9.

43. Offer $\mathrm{G}$, Trinick J. On the mechanism of water holding in meat: the swelling and shrinking of myofibrils. Meat Sci. 1983;8:245-81.

44. Salwani MS, Adeyemi KD, Sarah SA, Vejayan J, Zulkifli I, Sazili AQ. Skeletal muscle proteome and meat quality of broiler chickens subjected to gas stunning prior slaughter or slaughtered without stunning. CyTA J Food. 2015. doi:10.1080/19476337.2015.1112838.

45. Huff-Lonergan E, Lonergan SM. Mechanisms of water-holding capacity of meat: The role of postmortem biochemical and structural changes. Meat Sci. 2005;71:194-204.

46. Adeyemi KD, Sabow AB, Abubakar A, Samsudin AA, Sazili AQ. Effects of dietary oil blend on fatty acid composition, oxidative stability and physicochemical properties of Longissimus thoracis et lumborum muscle in goats. Anim Sci J. 2016. doi: 10.1111/asj.12597.

47. Traore S, Aubry L, Gatellier P, Przybylski W, Jaworska D, Kajak-Siemaszko K, Santé-Lhoutellier V. Higher drip loss is associated with protein oxidation. Meat Sci. 2012;90:917-24.

48. Kristensen L, Purslow PP. The effect of ageing on the water-holding capacity of pork: Role of cytoskeletal proteins. Meat Sci. 2001:58:17-23.

49. Purchas R. An assessment of the role of $\mathrm{pH}$ differences in determining the relative tenderness of meat from bulls and steers. Meat Sci. 1990:27:129-40.

50. Aghwan ZA. Effects of iodine and selenium supplementation on growth, carcass characteristics and meat quality of crossbred Kacang goats. PhD thesis. Serdang: Univeristi Putra Malaysia; 2013. p. 186.

51. Watanabe A, Daly C, Devine C. The effects of the ultimate $\mathrm{pH}$ of meat on tenderness changes during ageing. Meat Sci. 1996;42:67-78.

52. Torrescano G, Sanchez-Escalante A, Gimenez B, Roncales P, Beltrán JA. Shear values of raw samples of 14 bovine muscles and their relation to muscle collagen characteristics. Meat Sci. 2003;64:85-91.
53. Mercier $Y$, Gatellier P, Viau M, Remignon $H$, Renerre M. Effect of dietary fat and vitamin $\mathrm{E}$ on colour stability and on lipid and protein oxidation in turkey meat during storage. Meat Sci. 1998;48:301-18.

54. Madhavi D, Carpenter CE. Aging and processing affect color, metmyoglobin reductase and oxygen consumption of beef muscles. J Food Sci. 1993:58:939-42.

55. Bekhit A, Faustman C. Metmyoglobin reducing activity. Meat Sci. 2005;71:407-39.

56. Lynch A, Kerry J, O'sullivan M, Lawlor J, Buckley D, Morrissey P. Distribution of a-tocopherol in beef muscles following dietary a-tocopheryl acetate supplementation. Meat Sci. 2000:56:211-4.

57. Irie M, Fujita K, Sudou K. Changes in a-tocopherol concentrations in plasma and tissues from Japanese Beef cattle fed by two methods of Vitamin $E$ supplementation. Asian-Austral J Anim Sci. 1998;12:810-4.

58. Adeyemi KD, Olorunsanya AO. Comparative analysis of phenolic composition and antioxidant effect of seed coat extracts of four cowpea (Vigna unguiculata) varieties on broiler meat. Iranian J App Anim Sci. 2012;2:343-9.

59. Olorunsanya AO, Adeyemi KD, Babatunde IA. Effect of Bamboo (Bambusa valgaris) and Elephant grass (Pennisetum purpureum) leaf extracts on Oxidative Stability of Cooked and Raw Broiler Meat. J Agr Res Dev. 2011:10:1-10

60. Greene B, Cumuze T. Relationship between TBA numbers and inexperienced panelists' assessments of oxidized flavor in cooked beef. J Food Sci. 1982;47:52-4.

61. Martinaud A, Mercier Y, Marinova P, Tassy C, Gatellier P, Renerre M. Comparison of oxidative processes on myofibrillar proteins from beef during maturation and by different model oxidation systems. J Agr Food Chem. 1997:45:2481-7.

62. Maqsood S, Abushelaibi A, Manheem K, Al Rashedi A, Kadim IT. Lipid oxidation, protein degradation, microbial and sensorial quality of camel meat as influenced by phenolic compounds. LWT-Food Sci Technol. 2015;63:953-9.

63. Sabow AB, Zulkifli I, Goh YM, Ab Kadir MZA, Kaka U, Imlan JC, et al. Bleeding efficiency, microbiological quality and oxidative stability of meat from goats subjected to slaughter without stunning in comparison with different methods of pre-slaughter electrical stunning. Plos one. 2016. doi:10.1371/journal.pone.0152661.

64. Nakyinsige K, Sazili AQ, Aghwan ZA, Zulkifli I, Goh YM, Bakar FA, Sarah SA Development of microbial spoilage and lipid and protein oxidation in rabbit meat. Meat Sci. 2015;108:125-31.

65. Bandman $\mathrm{E}, \mathrm{Zdanis} \mathrm{D}$. An immunological method to assess protein degradation in post-mortem muscle. Meat Sci. 1988;22:1-19.

66. Gil M, Ramírez JA, Pla M, Arino B, Hernández P, Pascual M, Blasco A, Guerrero L, Hajós G, Szerdahelyi EN, Oliver MÁ. Effect of selection for growth rate on the ageing of myofibrils, meat texture properties and the muscle proteolytic potential of $m$. longissimus in rabbits. Meat Sci. 2006;72:121-9.

67. Shi-Zheng G, Su-Mei Z. Physiology, affecting factors and strategies for control of pig meat intramuscular fat. Recent Patents on Food, Nutr Agr. 2008;1:59-74.

68. Enser M, Hallett KG, Hewett B, Fursey GAJ, Wood JD, Harrington G. Fatty acid content and composition of UK beef and lamb muscle in relation to production system and implications for human nutrition. Meat Sci. 1998:49:329-41.

69. Adeyemi KD, Ebrahimi M, Samsudin AA, Sabow AB, Sazili AQ. Carcass traits, meat yield and fatty acid composition of adipose tissues and supraspinatus muscle in goats fed blend of canola oil and palm oil. J Anim Sci Technol. 2015;57:42.

70. Muíño I, Apeleo E, de la Fuente J, Pérez-Santaescolástica C, Rivas-Cañedo A, Pérez C, Lauzurica S. Effect of dietary supplementation with red wine extract or vitamin $\mathrm{E}$, in combination with linseed and fish oil, on lamb meat quality. Meat Sci. 2014;98:116-23.

71. Díaz M, Cañeque V, Sánchez C, Lauzurica S, Pérez C, Fernández C, De la Fuente J. Nutritional and sensory aspects of light lamb meat enriched in $n-3$ fatty acids during refrigerated storage. Food Chem. 2011;124:147-55. 